\title{
Ouro, porcos, escravos e café: as origens das fortunas oitocentistas em São Pedro de Cantagalo, Rio de Janeiro (últimas décadas do século XVIII e primeiras do XIX)
}

Gold, pigs, slaves and coffee: the origins of nineteenth century fortunes in São Pedro de Cantagalo, Rio de Janeiro (last decades of the eighteenth century and first of the nineteenth centuryl

\section{SHEILA DE CASTRO FARIA'}

Universidade Federal Fluminense / Niterói, RJ, Brasil

RESUMO: O município de Cantagalo, no estado do Rio de Janeiro, tem sua história ligada à exploração de ouro, criação de porcos e produção de alimentos para o mercado interno, e à cafeicultura escravista e mercantil exportadora. Analiso a construção do cotidiano material da região das "Novas Minas dos Sertões de Macacu" ou de "Cantagalo", como foi denominada no fim do século XVIII, e vila de São Pedro de Cantagalo em 1814, entre as últimas décadas do século XVIII e as primeiras do XIX. Utilizo como base documental inventários post-mortem, correspondência oficial trocada entre autoridades coloniais e metropolitanas, registros paroquiais de batizados, casamentos e óbitos e artigos de periódicos da imprensa do Rio de Janeiro.

PALAVRAS-CHAVE: Extração ilegal de ouro. Escravidão. Cotidiano material cafeicultor escravista. Imigrantes suíços. Cultura material.

ABSTRACT: The municipality of Cantagalo in the state of Rio de Janeiro is historically linked to gold exploration, the breading of pigs and to the production of food for the domestic market and of coffee by slaves for export markets. I will analyze the construction of the material daily life of the region "Novas Minas dos Sertões de Macacu" or "Cantagalo", as it was named at the

1. Professora Titular em História do Brasil aposentada do Departamento de História da Universidade Federal Fluminense (UFF). E-mail: <castrofaria@gmail.com>. 
2. Utilizo o termo "cotidiano material" para indicar os objetos utilizados no dia a dia das comunidades, tanto no setor como na esfera da produção econômica (agrícola, pastoril, extrativa etc.), assim como os recursos ambientais existentes e suas diversas utilizações por um grupo determinado no tempo e no espaço. Assim, o termo não significa fatos menores, de micro acontecimentos domésticos, mas da posse ou confecção de bens materiais utilizados repetidamente ou que se transformam cotidianamente.

3. Cf. entre outros, o clássico Grandeza e decadência do café no Vale do Paraíba: com referência especial ao município de Vassouras, de 1961, reeditado com o título Vassouras: um munícipio brasileiro do café, 18501900, de Stein (1990); E o Vale era o escravo: Vassouras, século XIX: senhores e escravos no coração do Império, de Salles (2008); As memórias da viscondessa: família e poder no Brasil Império, de Muaze (2008); e Barões do café e sistema agrário escravista: Paraíba do Sul/Rio de Janeiro (18301888), de Fragoso (2013).

4. É o caso, por exemplo, dos municípios de Vassouras, Paraíba do Sul e Valença, áreas que funcionaram como rota de passagem entre São Paulo, Minas Gerais e Rio de Janeiro, no século XVIII, com ocupação rarefeita, geralmente ranchos para atender aos viajantes, motivo pelo qual deixaram poucos registros escritos de sua ocupação.

5. Muaze; Salles (2015). end of the eighteenth century. Later, it became known as the city of São Pedro de Cantagalo, in 1814 , it retained this name through the last decades of the eighteenth century and the first decades of the nineteenth century. The documental basis used are post-mortem inventories, official correspondence exchanged between colonial and metropolitan authorities, parochial records of baptism, marriage and death and newspaper articles of the Rio de Janeiro press.

KEYWORDS: Illegal extraction of gold. Slavery. Material daily life of slave labor on coffee production. Swiss immigrants. Material culture.

\section{INTRODUÇÃO}

objetivo deste artigo é analisar a construção do cotidiano material ${ }^{2}$ de uma área em processo de ocupação econômica na vigência do trabalho escravo. A constituição das fortunas cafeeiras escravistas da região se dá provavelmente de forma semelhante à de outras áreas do Vale do Paraíba, embora não existam estudos específicos sobre elas para anos anteriores a 1830. As pesquisas empíricas sobre as principais regiões do vale cafeeiro fluminense têm como ponto de partida o fim da década de 1820, não antes; ${ }^{3}$ o que pode ser justificado por só constarem documentos a partir dessa época, embora a região possa ter uma ocupação mais antiga. ${ }^{4}$ Além do mais, pesquisadores que se debruçam sobre a história do café do século 19 apresentam hoje um enfoque mais teórico que empírico, principalmente os que concordam com a ideia de que a cafeicultura do Vale foi estabelecida com base no que seria uma "segunda escravidão". 5 Assim, a forma como os primeiros povoadores utilizaram os recursos ambientais e humanos disponíveis na implementação da lavoura cafeeira pode ter sido semelhante em várias regiões e períodos do Brasil. Mas havia diferenças conjunturais, que resultaram em organizações sociais e culturais que definiam o diferencial entre uma região e outra, dentro, é claro, do sistema escravista vigente.

É o caso dos Sertões das Cachoeiras de Macacu ou Sertões de Cantagalo, no decorrer do século 18, região batizada de Novas Minas de Cantagalo a partir de meados da década de 1780 e, finalmente, de vila de São Pedro de Cantagalo, no 
século 19. Analisei inventários post mortemº das primeiras décadas do século 19, informações contidas na correspondência entre os vice-reis sediados no Rio de Janeiro, os governadores da capitania de Minas Gerais e as diversas autoridades do governo português, da segunda metade do século 18 e início do 19, referências em periódicos (a exemplo do Jornal do Commercio e da Gazeta do Rio de Janeiro), registros de batizados, casamentos e óbito de fins do século 18 e das três primeiras décadas do século 19, e informações contidas em cartas particulares entre suíços coligidas, transcritas e traduzidas pelo historiador Henrique Bon.?

Avaliei escolhas individuais referentes à atividade econômica, construção ou compra de benfeitorias, lavouras e "recheios das casas", 8 em uma área recém-aberta à ocupação agrária que viria a ser um dos mais ricos municípios cafeeiros do Vale do Paraíba fluminense no século 19, que contou ainda com presença marcante de população migrante europeia, especialmente de suiços, a partir de 1820.

\section{CANTAGALO OU NOVA FRIBURGO?}

atual município de Cantagalo, situado no norte do estado do Rio de Janeiro e localizado na divisa com o estado de Minas Gerais (Figura 1), talvez seja um dos menos conhecidos pela historiografia brasileira no que se refere a sua posição no complexo cafeeiro do Vale do Paraíba. Para se avaliar a riqueza da região, no Recenseamento de 1872, em Cantagalo habitavam 29.453 pessoas, 57\% delas (16.805), escravas. ${ }^{9} \bigcirc$ município de Paraíba do Sul, considerado por João Fragoso um dos mais povoados do Vale do Paraíba fluminense e de elevada concentração de população escrava nas mãos de uma poderosa elite, ${ }^{10}$ tinha 37.461 habitantes, 46\% deles, escravos, proporção menor do que a de Cantagalo, do que se supõe que Cantagalo estava entre as principais regiões de cafeicultura escravista e mercantil de grande porte. "' Em praticamente todas as pesquisas e trabalhos que tratam da história agrária do Vale, entretanto, somente alguns mencionam, de passagem, a cafeicultura em Cantagalo, com algumas exceções, como as dissertações de Gelsom Rozentino de Almeida e Eliana Vinhaes. ${ }^{12}$ Outros historiadores nem mesmo identificam Cantagalo como pertencendo à macrorregião do vale do Paraíba, ${ }^{13}$ mas como parte da região Serrana, que tem o município de Nova Friburgo, hoje, como referência central.

Em termos geográficos, Cantagalo faz parte do Vale do Paraíba, com as mesmas conformações geomorfológicas ${ }^{14}$ (Figura 1). Por conta desse desconhecimento, até mesmo erros iconográficos foram cometidos: na edição de 1980 do livro do suíço J. J. Tschudi, ${ }^{15}$ publicado pela editora Itatiaia e pela Editora da Universidade de São
6. Agradeço ao professor Wesley Gonçalves, coordenador do Centro de Memória de Cantagalo, Polo CEDERJ, História/UniRio, e à aluna de história Mariana Silveira, a competência na transcrição dos inventários post-mortem aqui analisados.

7. Bon (2006).

8. Variava de região para região, mas era a forma usual referida em inventários post mortem para indicar os objetos móveis existentes no interior dos domicílios, incluindo rouparia, louças, instrumentos de cozinha etc.

9. Disponível em: <https:// goo.gl/D4Ykoq>. Acesso em: 5 abr. 2018.

10. Fragoso (2013, p. 11).

11. O município de Vassouras, considerado um dos maiores produtores de café para exportação do Vale do Paraíba Fluminense, tinha 39.253 habitantes, 20.168 escravos, que representavam $52 \%$ da população. Disponível em: <https:// goo.gl/D4Ykoq>. Acesso em: 5 abr. 2018.

12. Vinhaes (1992); Almeida, Gelsom (1995).

13. Márcia Malheiros separa Cantagalo do Vale do Paraíba na passagem: "deixando de indicar a presença de grupos Coroados em capitanias vizinhas e em áreas de outras regiões fluminenses, como o atual município de Cantagalo e o Vale do Paraíba" (2008, p. 158).

14. Uma das principais características geomorfológicas do Vale do Paraíba é a existência de muitos morros de "meia laranja" (morros arredondados) e, em termos climáticos, apresenta temperaturas nem muito frias nem excessivamente quentes, sem geadas (que eram fatais para o café). 
15. Tschudi esteve na América em duas ocasiões. Na segunda, a partir de 1857 , entre 1860 e 1866 atuou como ministro plenipotenciário da Confederação Helvética, com a função de estudar os problemas da imigração suíça no Império do Brasil (1980).

16. Ao final do livro, há a seguinte informação: "Os filmes do texto e das ilustrações foram gentilmente cedidos por José de Barros Martins, do acervo editorial da prestigiosa Livraria Martins Editora, de São Paulo" (Ibidem, p. 219).

17. Ibidem, p. 91.

18. A descoberta de que a foto foi tirada em Cantagalo e não no Paraguai foi divulgada por Mônica Carneiro e Lia Jordão, na Revista de História da Biblioteca Nacional, em 2014. No livro Coleção Princesa Isabel: fotografia do século XIX, Pedro Corrêa do Lago afirmou que a foto "mostra a improvável presença da Princesa Isabel no Quartel General no Paraguai, visitado pelo Conde d'Eu, onde a herdeira do trono almoçou sob um teto de sapê em companhia dos outros oficiais reunidos em torno do comandante das forças aliadas, seu marido". Jordão; Carneiro (2014, p. 74-83). Há exceções, como o trabalho de Marieta de Moraes Ferreira (2008), que entende o município de Nova Friburgo, no século XIX, como uma rota de passagem entre a rica região cafeeira de Cantagalo e a cidade do Rio de Janeiro.

19. Uma análise sobre as condições da cafeicultura no século XIX e as condições geográficas de sua produção encontra-se em Laërne (1885).

20. Claro que a circunscrição do município hoje é bem menor, pois teve áreas desmembradas para a criação de novos municípios.
Paulo, ${ }^{16}$ uma imagem da vila de Cantagalo é indicada como sendo de Nova Friburgo ${ }^{17}$ (Figura 2). Até há pouco tempo, uma fotografia da princesa Isabel e sua comitiva em um almoço era atribuída a uma possível visita dela aos campos da Guerra do Paraguai - imagem que se comprovou ser, na verdade, o registro de uma visita a Cantagalo, o que configura o desconhecimento da região por parte de historiadores e editores. ${ }^{18}$

Vassouras, Valença, Paraíba do Sul, Piraí e demais municípios do Vale do Paraíba fluminense cafeeiro e escravista sempre foram identificados por sua riqueza e decadência ligadas ao café. Por que não Cantagalo? A que se deve essa situação?

Penso que uma das explicações possíveis está no fato de a família Clemente Pinto, considerada uma das mais ricas famílias de fazendeiros do Império, ter recebido títulos de barão, conde e visconde de "Nova Friburgo", o que poderia sugerir, para os que não conheciam a região, que suas terras estivessem em Nova Friburgo. As terras que formariam a colônia de Nova Friburgo foram desmembradas do território da Vila de Cantagalo, que foi criada para receber suíços, chegados em 1819, época do então já rei D. João VI. Só que as fazendas de café e as escravarias da família Clemente Pinto estavam em Cantagalo. O município de Nova Friburgo não tem, em geral, clima adequado para o cultivo da rubiácea, com temperaturas muito baixas em grande parte do ano e geadas constantes, condições fatais para o café. ${ }^{19}$ É possível que a posição destacada desses nobres, com riquezas originadas no comércio de grosso trato - particularmente no tráfico de escravos - e na produção de café, com títulos vinculados ao município de Nova Friburgo, tenha provocado esse erro historiográfico.

Por outro lado, hoje, a população de Cantagalo não chega a 20 mil pessoas, ${ }^{20}$ enquanto Nova Friburgo conta com mais de $182 \mathrm{mil}$, ou seja, nove vezes mais habitantes do que a região da qual se originou. $\bigcirc$ fato é que a importância demográfica e econômica de Nova Friburgo sobrepujou a de Cantagalo, e o município é, atualmente, desconhecido por muitos, ou então considerado como uma extensão de Nova Friburgo.

\section{DOS SERTÕES DE MACACU ÀS NOVAS MINAS DE CANTAGALO}

Quando da criação da vila de São Pedro de Cantagalo, em 9 de março de 1814, suas terras confrontavam com o Rio Paraíba do Sul, ao norte, limite de Minas Gerais, e os municípios fluminenses de Macacu, Magé, Macaé e Campos dos Goytacazes. Seu extenso território foi recortado, no decorrer do Oitocentos, para dar origem a diversos municípios: Nova Friburgo, Carmo, Sumidouro, Duas 


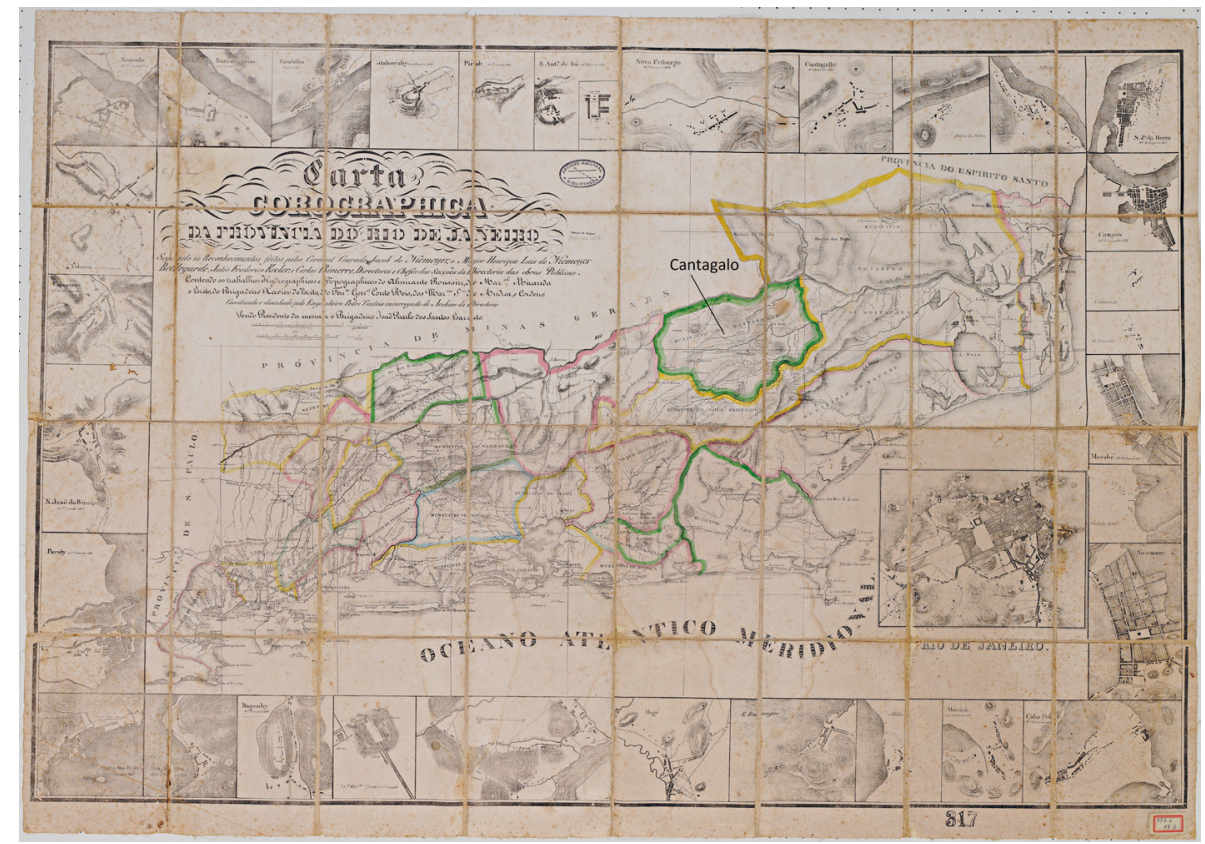

Figura 1 - Carta corográfica da província do Rio de Janeiro, segundo os reconhecimentos feitos por Conrado Jacob de Niemeyer, o Major Henrique Luis de Niemeyer Bellegarde, Júlio Frederico Koeler e Carlos Rivierre, diretores e chefes das seções de obras públicas, sem data.

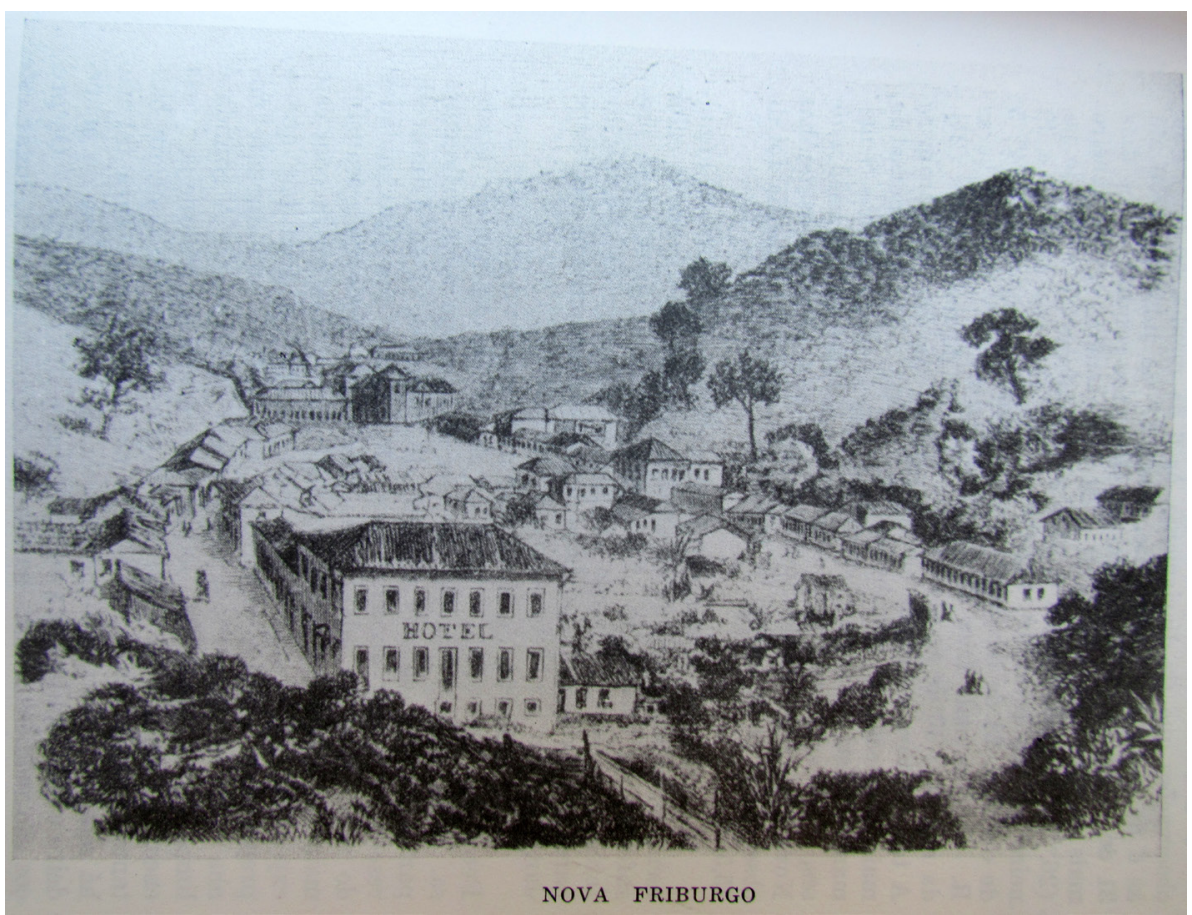

Figura 2 - Vista da cidade de Cantagalo, Rio de Janeiro. Pintura da década de 1860²1. Fonte: Tschudi (1980, p. 91).
21. No livro do cônsul suíço Johann Jakob von Tschudi, a referência da imagem é "Nova Friburgo". Na verdade, é a vista da cidade de Cantagalo, Rio de Janeiro, em pintura da década de 1860, utilizada como folha de rosto do bloco de notas da Farmácia Peckolt, localizada na Rua Direita. Theodore Peckolt foi um naturalista germânico que residiu em Cantagalo por duas décadas, em meados do século XIX. 
22. Dias (1942). O autor publicou também um romance com o título "O Mão de Luva” (1953), detalhando a saga do aventureiro, talvez de 1953, como informa um comentário sobre o romance feito pelo Dr. Armando Gonçalves, publicado no jornal O Fluminense de 23 de janeiro de 1954. Acácio Ferreira Dias fez parte de uma geração de literatos empenhados em estimular o sentimento nativista regional através da pesquisa histórica local, relacionando-a à História do Brasil. Cf. Fernandes (2009).

23. Até a República, com a instauração do matrimônio civil, o casamento eclesiástico (católico e, depois, o de outras igrejas permitidas no Brasil, a partir de 1810) era o único meio para a legalização de uma união. Para isso, os noivos tinham de dar ciência ao seu pároco de suas pretensões. O sacerdote fazia a denunciação, ou proclama, sobre os noivos que estavam para se casar, para que quem soubesse de algum impedimento ao matrimônio o declarasse ou usasse de meio legal de o impedir. Os "processos de banhos matrimoniais", como a historiografia o denomina, contêm dados sobre os noivos (origem, filiação, estado matrimonial - solteiro ou viúvo -, impedimentos etc.) que os assentos de registros paroquiais de casamento não informam. Além disso, também indicam os impedimentos, que são vários. Para informações sobre os impedimentos canônicos, cf. Vide (1853).

24. Processo... (1775 apud Oliveira, 2008, p. 138-139).
Barras, Cordeiro, Macuco, Bom Jardim, Santa Maria Madalena, Trajano de Moraes, São Sebastião do Alto.

A história de ocupação da região tem um mito de origem por ter sido lugar de garimpo ilegal de ouro, com um chefe ou líder que tinha uma alcunha curiosa: "Mão de Luva". Até bem pouco tempo atrás, pouco se sabia sobre sua origem. Seu nome era Manoel Henriques. No romance Mão de Luva, publicado por Acácio Ferreira Dias, jornalista e político indicado por Getúlio Vargas para ocupar a prefeitura da então cidade de Cantagalo de 1930 a 1935, se consolidou uma memória romântica e espetacular do considerado "fundador" da cidade. Ele seria um nobre português (duque de Santo Tirso), apaixonado pela princesa D. Maria, filha do rei D. José I, e se aliou à família Távora na conspiração contra o rei, em 1758. Os envolvidos foram enforcados a mando do já poderoso ministro Sebastião José de Carvalho e Melo (futuro marquês de Pombal), mas o duque teria sido poupado, condenado somente ao desterro para o Brasil, por interferência da princesa junto ao pai. Em seus últimos dias em Portugal, D. Maria teria ido ao calabouço onde o duque se encontrava e the dado um beijo na mão, motivo pelo qual passou a usar uma luva, para manter a memória da amada. Foi assim alcunhado de "Mão de Luva", e assim referido em documentos da segunda metade do século 18 no Brasil. 22

O historiador Rodrigo Oliveira pesquisou grupos de garimpeiros ilegais nas serras da Mantiqueira (liderado por um homem alcunhado de "Montanha") e dos Órgãos (chefiado por "Mão de Luva"), e pôde comprovar, finalmente, o lugar de nascimento de Manuel Henriques. No Arquivo Eclesiástico da Arquidiocese de Mariana, achou seus banhos matrimoniais, ${ }^{23}$ o de seu irmão, Ignácio da Silva, e o de seu pai, Manuel Henriques Malho. $\bigcirc$ processo de Manuel Henriques, datado de 1775, o indica como nascido na freguesia de Ouro Branco, do Bispado de Mariana e, no momento do casamento, residente na freguesia de Nossa Senhora da Conceição de Guarapiranga, do mesmo bispado. Era filho de Manuel Henriques Malho e de Maria da Silva (natural da freguesia de Guaratinguetá, Bispado de São Paulo). Sua noiva, Maria de Souza, designada como "Dona" era viúva de Manoel da Costa Ferreira e filha legítima de pessoa também titulada em Guarapiranga, o capitão Antônio de Souza Ferreira, e de Florência Luiza de Miranda. ${ }^{24}$

Nem nobre nem nascido em Portugal, Manuel Henriques, entretanto, se casou em uma família mais titulada do que a dele, o que significa que tinha inserção nas famílias prestigiadas da freguesia de Nossa Senhora da Conceição de Guarapiranga. Quero salientar que era um indivíduo bem posicionado na hierarquia da sociedade do Brasil colonial, assim como outros que se dirigiram para os sertões de Macacu, tanto nos anos anteriores à década de 1780, quanto 
nos seguintes, como detalharei adiante. Não eram pobres e, em alguns casos como o do próprio Manuel Henriques, faziam parte do grupo dos "homens bons" 25 da colônia, em particular de Minas Gerais.

Manuel Henriques foi considerado pelas autoridades coloniais o líder desse grupo de garimpeiros. Não há indicação precisa do ano em que começou a faiscar ouro, mas as cartas trocadas entre as autoridades coloniais e as do reino fazem pressupor que foi entre 1765 e 1775.26

A localização do garimpo considerado ilegal e, principalmente, os caminhos que para lá levavam, eram desconhecidos das autoridades coloniais, e a região era ocupada por muitos grupos indígenas. Os documentos indicam as seguintes nações: Coropó, Chopotó, Puris, Coroados e Goitacazes, embora sejam indicações gerais e sem grande confiabilidade. ${ }^{27} \bigcirc$ primeiro registro topográfico da região se encontra em um mapa de 1767, elaborado pelo sargento e governador da Fortaleza do Castelo São Sebastião da cidade do Rio de Janeiro, Manoel Vieyra Leão, encomendado pelo vice-rei do Estado do Brasil, Conde da Cunha (D. Antônio Alvarez da Cunha). Fazia parte das cartas topográficas da Capitania do Rio de Janeiro. ${ }^{28}$ A região onde hoje se localiza município de Cantagalo recebeu somente a indicação: "Certão dos Índios Bravos"29 (Figura 3).

Durante os vinte anos seguintes à publicação do mapa de Vieyra Leão, - "Sertão dos Índios Bravos" foi alvo do interesse dos governantes e sistematicamente referido na correspondência oficial como ocupado por garimpeiros indesejáveis. ${ }^{30}$ Sob o governo do vice-rei Luís de Vasconcellos e Souza (de 1778 a 1790), ações mais efetivas por parte dos governantes foram realizadas para desmobilizar a "rancharia" 31 de Manuel Henriques, não sem grande esforço, principalmente a partir de 1783.

Conforme as diligências se intensificavam, detalhes sobre o garimpo foram revelados por meio de inquirições a comerciantes ou tropeiros acusados de levar mantimentos para o bando. Informaram que o garimpo era habitado por "brancos e pretos" e tinha "rancharias" com dezenas de casas, e nele, além de Manuel Henriques, o Mão de Luva, estavam seus três irmãos: Antônio Henriques, Ignácio da Silva (às vezes referido como Henriques) e Félix da Silva, os últimos, irmãos por parte materna. ${ }^{32}$ Não eram os únicos com parentesco. Os irmãos Lopes, José e Dionízio também faziam parte do grupo. $\bigcirc$ garimpo era um empreendimento familiar, composto por irmãos, e escravista, pois todos eram proprietários de escravos, ${ }^{33}$ conforme se detalha nos documentos relativos à devassa. ${ }^{34} \mathrm{E}$ quase todos eram originários, senão de nascimento, pelo menos de moradia, da freguesia de Nossa Senhora da Conceição de Guarapiranga ${ }^{35}$ e vizinhanças, bispado de Mariana, na capitania de Minas Gerais.
25. "Homem bom" era a forma usual para se referir a uma pessoa de bem, fidalgo ou nobre no Brasil colonial.

26. O melhor estudo empírico sobre a correspondência trocada entre as autoridades, que trata do garimpo ilegal e da prisão dos acusados nos Sertões da Cachoeiras de Macacu, é o de José Antônio Soares de Souza (1980).

27. Malheiros considera as indicações sobre as nações indígenas da região de Cantagalo generalistas, e que talvez abarquem uma gama maior de etnias do que as citadas na documentação (2008, p. 145).

28. Leão (1767).

29. Uma interessante análise sobre os significados de "sertão" se encontra no trabalho de Malheiros (2008).

30. Oliveira (2008) apresenta uma boa argumentação sobre as dificuldades das autoridades sediadas no Rio de Janeiro em mapear a região e em conhecer o local exato do garimpo de Manuel Henriques.

31. No dicionário de Silva (1813, p. 550), "rancho" significa: a divisão em que se ajuntam, dormem e comem os da mesma camarada; Bando, facção, parcialidade de poucos; Casa, ou tenda removível, que se faz pelos caminhos.

32. Segundo Oliveira (2008, p. 139-141), Manuel seria um filho adulterino que foi depois considerado legítimo. Os dois primeiros, de sobrenome Silva, seriam filhos de Maria da Silva e de seu defunto marido, Antônio Simões, assassinado no início da década de 1750 no caminho de Serro do Frio. O casamento dela, viúva, com Manuel Henriques Malho, pai do Mão de Luva, ocorreu provavelmente em 1761. 
33. Os documentos envolvendo o grupo de Mão de Luva que se encontram no Arquivo Nacional, no Arquivo Histórico Ultramarino, em versão digital, e na Seção Colonial do Arquivo Público Mineiro estão sendo revisados por mim e por Rodrigo de Oliveira para futura publicação em parceria com o Centro de Memória, Pesquisa e Documentação de Cantagalo.

34. O conjunto de documentos relativos ao garimpo ilegal de Mão de Luva se encontra em vários fundos: Casa dos Contos de Minas Gerais, Arquivo Histórico Ultramarino, Biblioteca Nacional e Arquivo Nacional. A correspondência era basicamente entre o vice-rei, no Rio de Janeiro, D. Luis de Vasconcellos e Souza e o secretário de Estado, da Marinha e do Ultramar no reinado de D. José I.

35. Guarapiranga, hoje denominada Piranga, dista cerca de 250 quilômetros do município de Cantagalo.

36. O vice-rei Luís de Vasconcellos acreditava que Luís da Cunha Meneses, governador de Minas, estava envolvido no contrabando de ouro. Oliveira (2008, p. 95-127) sugere que Mão de Luva e Cunha Meneses se conheciam e tinham acordos no empreendimento.

37. "Descoberto", como substantivo, era o termo utilizado na correspondência para indicar o garimpo considerado ilegal. Não tenho certeza sobre o significado, mas Silva (1813, p. 559) registra "descoberto", substantivo masculino, como o mundo conhecido e achado pelos navegantes e viajantes, e por "lugar descoberto" raso, não fortificado. Não acho que tenha sido usado como um lugar que foi achado, descoberto.

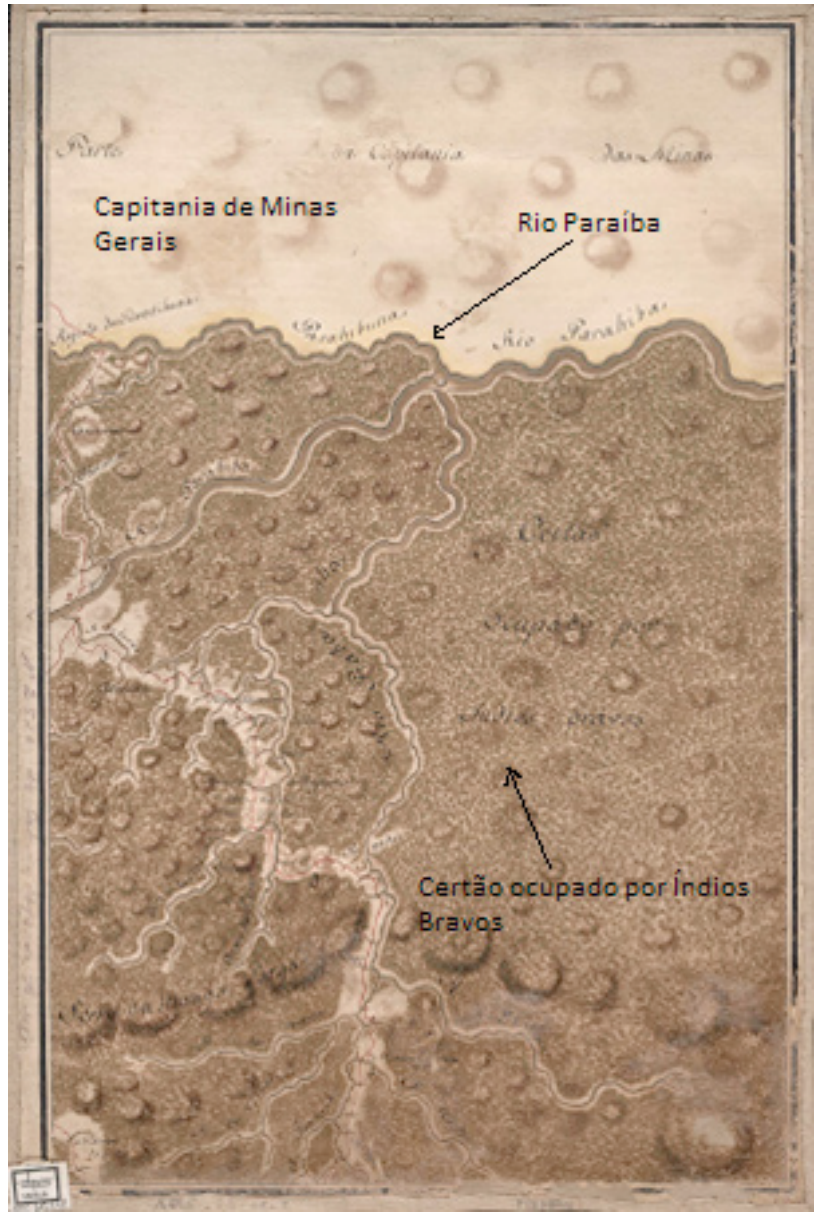

Figura 3 - Detalhe do mapa de Vieyra Leão (1767).

Os "contrabandistas" tiveram condições de investir em uma complexa estrutura que envolvia vasta rede de abastecimento, a principal delas oriunda da capitania de Minas Gerais, atravessando o rio Paraíba do Sul, como se depreende da documentação anexada aos autos da devassa que se procedeu a partir de 1784. Sob as ordens do governador de Minas Gerais, Luís da Cunha Meneses, e à revelia do vice-rei Luís de Vasconcellos, ${ }^{36}$ um destacamento militar, sob a liderança do sargento-mor do regimento de cavalaria de Minas Gerais, Pedro Afonso Galvão de São Martinho, entrou nos Sertões das Cachoeiras de Macacu com o objetivo de conhecer o local exato do "descoberto", 37 conforme se referiam ao garimpo ilegal na época. Cunha Meneses justificou a iniciativa argumentando não saber se os ditos Sertões, já neste momento denominado alternativamente de "Macacu" ou de "Cantagalo", pertenciam a Minas Gerais ou ao Rio de Janeiro. São Martinho iniciou a inquirição de pessoas que transitavam pelos portos do rio Paraíba, em particular na localidade chamada de Porto do Cunha (hoje corresponde ao $3^{\circ}$ Distrito do município do Carmo, no estado do Rio de Janeiro). 
Pelas respostas dos inquiridos, depreende-se que as mercadorias direcionadas para o garimpo eram transportadas em lombos de mulas ou bestas, bastante numerosas, por sinal, como consta no depoimento que o sargento-mor tirou de

João Baptista Ferreira, filho de Diogo Ferreira, morador no Rio da Pomba distante da dita Aldeia [de São Manoel do Rio da Pomba, um dos lugares onde São Martinho se encontrava em diligência para averiguar a localização do garimpo ilegal] um quarto de légua o qual vem do Descoberto com treze Bestas de José Francisco, morador no Xopotó, e oito do Alferes Theotônio Francisco, morador no Ribeirão de S. Bento, e onze de Pedro Lemos, morador na Espera, e três do dito João Baptista Ferreira, que ao todo são trinta e cinco, que levou com mantimentos, para o Descoberto. ${ }^{38}$

Cartas trocadas entre Antônio Henriques, irmão de Mão de Luva, e o soldado Sebastião Craveiro de Faria (uma sem data, escrita por Antônio Henriques a Craveiro, e duas de abril e maio de 1786, assinadas por Craveirol foram anexadas aos autos da devassa e indicam um relacionamento comercial estável entre o soldado e Antônio Henriques. Na carta de abril há referências às mercadorias entradas naquele sertão:

também tenho notícia que o senhor Manuel Henriques pediu a V. mercê doze oitavas de ouro de mantimentos [...] pois eu quando fui levei três alqueires de farinha, um de feijão, e três banhas, e sal muito pouco, e os seus negros doze estão comendo [...] diga-the que o seu chumbo, e pólvora não the mando, pois já estava pronto, e pelo Felipe me dizer levava encomenda para o trazer. $^{39}$

Nos relatórios elaborados por São Martinho há referências a outras mercadorias que entraram no "descoberto": toucinho, rolos de fumo e aguardente. Também informam o que havia na região do garimpo: plantações de feijão, abóbora e milho, criação de galinhas e porcos e monjolos para fazer farinha. ${ }^{40}$ Os garimpeiros pagavam com ouro em pó, conforme apreensão de várias pessoas com oitavas de ouro em seu poder, como foi o caso de três negros, um do anspeçada [cabo] Bernardo dos Reis, chamado Domingos, e dois do soldado Sebastião Craveiro, chamados Gonçalo Angola e Antônio Congo: "em ouro em pó remetido em uma borracha para o dito Craveiro 80/8 [oitenta oitavas], e quatro e meia [oitavas] do dito negro Domingos". ${ }^{41}$

Depois das investigações, a empreitada foi bem-sucedida, encerrando em 1786 com a prisão do grupo. ${ }^{42}$ Em vez da ordem de invasão ao sertão vir do governo central, no Rio de Janeiro, procedeu do governo de Minas. A maior parte dos presos teve seus bens confiscados, dentre os quais mais de 600 oitavas de ouro. Também foram apreendidos instrumentos de trabalho, espingardas, espadas, facões etc. Suas roças de milho, mandioca, abóbora e feijão foram destruídas,
38. Carta de Pedro... (1784). Documento transcrito por Rodrigo de Oliveira.

39. Carta de Sebastião... (1786). Rodrigo Leonardo de Souza Oliveira, em sua dissertação, não cita estas passagens, mas nos forneceu a cópia dos documentos e suas transcrições.

40. Relatório... (1786). Interrogatório feito nas pessoas que chegarão a este Porto do Cunha, vindo do Descoberto de Macacu.

41. Ibidem.

42. Para o detalhamento do processo de captura do grupo, cf. Oliveira (2008). 
43. Ibidem, p. 125 e 133. Os documentos referentes ao interrogatório dos presos encontram-se na Seção Colonial do Arquivo Público Mineiro e foram analisados detalhadamente por Rodrigo Oliveira.

44. Ibidem, p. 125.

45. Esses documentos encontram-se disponíveis em dois fundos: o Projeto Resgate e a Coleção Casa dos Contos, sendo possível acessá-los através da Biblioteca Nacional Digital.

46. Erthal (2008).

47. Vasconcellos e Souza (1842, p. 28).

48. Os assentos de casamento passam a existir de 1825 em diante, mesmo assim fragmentados. assim como 21 casas. ${ }^{43}$ Seus mantimentos e criações foram doados aos índios. Aparentemente o grupo se relacionava bem com os indígenas da região. Há referência de que o "capitão dos Índios", de nome Joaquim, intercedeu por Manuel Henriques, solicitando ao sargento-mor Pedro Afonso Galvão de São Martinho, que o prendera, que não the fizesse mal. ${ }^{44}$

\section{DE MINAS PARA CANTAGALO: OURO E PRODUÇÃO DE ALIMENTOS}

Entre a prisão dos mineradores clandestinos, em 1786, e os primeiros documentos que registram o cotidiano da região das Novas Minas do Sertão de Cantagalo, há uma lacuna documental, preenchida esporadicamente por algumas cartas trocadas entre as autoridades coloniais e metropolitanas, ${ }^{45}$ cujas informações são de difícil comprovação, e fragmentos de registros paroquiais. São os únicos documentos até agora encontrados.

É difícil identificar corretamente a que atividade econômica as pessoas se dedicaram. Tudo indica que a "miragem do ouro", termo usado por Clélio Erthal no título de seu livro, ${ }^{46}$ os levou para lá, mas acredito que para alguns não se tratou só de miragem. A expectativa era encontrar outros veios auríferos, como refere o vice-rei Luís de Vasconcellos, que considerava os rios Macuco, Grande e Negro, e seus córregos, promissores. ${ }^{47}$

primeiro registro de batismo do livro da Igreja do Santíssimo Sacramento de Cantagalo data de 1790, mas o seguinte já pula para o ano de 1792; o de óbito, de 1789, tem o assento seguinte (na mesma página) de 1792.48 São fragmentos, na verdade, mas podem ser aproveitados para uma análise qualitativa. Consegui identificar nove famílias com filhos batizados antes de 1800, que representam alguns dos primeiros ocupantes do arraial já sob a administração colonial.

Os inventários só existem de 1815 em diante, e em bem pequeno número para esses primeiros anos. Presumo que possa ter havido inventários para os anos anteriores, pois havia proprietários falecidos com bens suficientes para redigirem testamentos e serem inventariados, mas não devem ter sido registrados em Cantagalo. $\bigcirc$ mais provável é que não existisse tabelião ou notário residentes antes da elevação do arraial de São Pedro de Cantagalo à categoria de Vila, em 9 de março de 1814 . Obviamente a região estava inscrita em alguma circunscrição administrativa e o testamento e/ou o inventário poderiam ser realizados no termo competente, mas as distâncias e os gastos deveriam ser excessivos para herdeiros 
em relação ao conjunto de bens que receberiam. Assim, a opção foi não realizar legalmente a listagem e a partição dos bens.

Um documento informa a ausência de oficial competente: em assento de óbito datado de 16 de novembro de 1802, da freguesia do Santíssimo Sacramento de Cantagalo, José Antônio de Barros, soldado do Regimento de Artilharia e que servia de Almoxarife na Casa da Superintendência do Ouro das Novas Minas, batizado na freguesia de Trindade de Cachoeiras de Macacu, casado, teve seu testamento transcrito. Nele, informou que estava gravemente enfermo e que precisava fazer "algumas disposições de seus bens e declarações relativas aos seus negócios" e necessitava do consentimento do Superintendente Geral para que "dê faculdades ao Escrivão da Superintendência deste distrito por não haver neste tabelião nem outro oficial de fé para que possa aceitar judicialmente as ditas disposições e declarações com validade de Testamento", 49 no que foi atendido.

Por mais alguns anos depois de 1802, o arraial não deve ter contado com oficiais "de fé", mas eles já estavam presentes em 18 15: "nesta Vila de São Pedro de Cantagalo em meu Cartório apareceu presente o inventariante José de Almeida Nunes", 50 de Ana Joaquina do Amor Divino, casada com o inventariante. Seu caso pode ter sido o de muitos que morreram antes de 1814 , cujas famílias não abriram inventário: Ana Joaquina tem seu registro de óbito datado de 7 de setembro de 1808, ${ }^{51}$ mas só teve seus bens inventariados em 1815. Nele consta o nome do escrivão: Jacome Vicente Bizio. ${ }^{52}$

Outra inventariada que faleceu muito antes da elaboração do inventário foi Sebastiana Maria de Jesus, casada com Antônio de Melo de Oliveira, sepultada em 13 de março de 1809, com inventário aberto somente em 1820.53 Outro, ainda, foi o Antônio de Oliveira Torres, enterrado em 19 de abril de 1808 e somente depois do falecimento da mulher foi aberto o inventário do casal, em 1819.54

Entre 1815 e 1820 somente seis inventários sobreviveram: dois deles são dessas nove famílias identificadas que tiveram registros de batismos de seus filhos até 1800. ${ }^{55}$ Foram elas: Ana Joaquina do Amor Divino, já citada, casada com José de Almeida Nunes, com inventário aberto em 1815, e a de Antônia Ferreira (ou Francisca, em alguns registros) Soares, casada com Antônio Teixeira de Lemos.

Não consta a naturalidade de Ana Joaquina e de José de Almeida Nunes, somente as de seus pais: todos foram indicados como nascidos no bispado de Angra, arquipélago dos Açores, itha portuguesa, mas Ana e José, em registros posteriores, constam como naturais do Rio de Janeiro e da llha do Pico (Açores), respectivamente.

Antônia Ferreira Soares, por sua vez, era filha do padre Vicente Ferreira Soares e de Isabel Maria Pereira. Vicente foi indicado como natural de São
49. Livro de assentos de óbito... (1789 a 1825 , p. 146). Todos os assentos paroquiais da Igreja estão digitalizados e se encontram no Centro de Memória, Pesquisa e Documentação de Cantagalo, Polo CEDERJ, História/UniRio.

50. Ana... (1815).

51. Registro de óbito de 7 de setembro de 1808 de Ana Joaquina do Amor Divino (Livro de assentos de óbito..., 1789 a 1825).

52. Nos registros de batismo da Freguesia do Santíssimo Sacramento de Cantagalo, ele batiza dois filhos, em 1812 e 1816, e é indicado como originário de Gênova e casado com Bárbara Maria da Silva, filha de portugueses da freguesia de Santa Maria, bispado de Lamego, Portugal. Não tenho explicação para o fato de estar uma pessoa nascida em Gênova atuando como escrivão no Brasil em 1815.

53. Registro de óbito de 13 de março de 1809 de Sebastiana Maria de Jesus (Livro de assentos de óbito..., 1789 a 1825 ; Sebastiana..., 1820).

54. Registro de óbito de 19 de abril de 1808 de Antônio de Oliveira Torres (Livro de assentos de óbito..., 1789 a 1825; Antônio..., 1819).

55. A pesquisa que desenvolvo ainda está em elaboração, e meu interesse, aqui, em destacar somente as famílias que tiveram filhos até 1800 foi justamente o de analisar a origem dos membros adultos dos domicílios que montaram as primeiras unidades produtivas da região sob controle régio. 
56. Livro de assentos de óbito... (1789 a 1825), grifos meus). Não tenho referência sobre a localização da referida fazenda, mas existe um município com este nome, Bom Jardim, desmembrado das terras de Cantagalo e de Nova Friburgo, em 1892, que pode ter sido o local da fazenda Bom Jardim. O que ajuda nessa suposição é o fato da fazenda ter sido referida em muitos registros de óbito como lugar de passagem para se chegar a Cantagalo, e o município atual de Bom Jardim está localizado nessa estrada (Bom Jardim, hoje, localiza-se entre Nova Friburgo e Cantagalo).

57. Livro de assentos de batismo... (1792-1817).

58. Sobre a relação entre migração e condições de vida, cf. Faria (1998).
Caetano, bispado de Mariana, provavelmente São Caetano do Xopotó lou Chopotól, região então sob a jurisdição de Guarapiranga, e Isabel, de Nossa Senhora da Conceição, da Comarca de Sabará (hoje cidade de Sabará), ou seja, ambos de Minas Gerais, assim como a filha, Antônia. O Padre Vicente Ferreira Soares realizou diversos ofícios na lgreja do Santíssimo Sacramento de Cantagalo, substituindo o vigário, e chegou a ser titular por um tempo.

O padre era proprietário da Fazenda do Bom Jardim, onde tinha oratório e realizava batizados, casamentos e óbitos, os quais eram posteriormente registrados nos livros de assentos da Matriz do Santíssimo Sacramento, como este:

Aos cinco dias do mês de fevereiro do ano de 1797 faleceu da vida presente com todos os sacramentos Francisca filha do Padre Vicente Ferreira Soares em outro tempo casado e assistente na sua fazenda do Bom Jardim e foi encomendada na forma do ritual romano e está sepultada no cemitério do dito Padre.56

Vicente Ferreira Soares havia se estabelecido nas Novas Minas de Cantagalo no início da década de 1790. Junto com ele estava um irmão, José Ferreira Soares - falecido em 21 de julho de 1805 e sepultado no cemitério da Fazenda do Bom Jardim -, além de filhos e netos (o primeiro registro de batismo de um neto do padre, em Cantagalo, é de 10 de novembro de 1794, filho justamente de sua filha inventariada em 1816). Foi padrinho de um neto, batizado em 13 de dezembro de 1811 , filho de seu filho Francisco Ferreira das Chagas. Gertrudes Ferreira Soares é outra filha, que tem filho batizado em $1^{\circ}$ de fevereiro de $1796 . .^{57}$

Em algum momento, ele criou ou comprou essa Fazenda do Bom Jardim, onde tinha um oratório dedicado a São Francisco de Paula la informação consta no batizado de Luiz, seu neto, de 15 de setembro de 1805). Teve vários descendentes registrados em Cantagalo, quase todos batizados ou casados em sua fazenda do Bom Jardim. As gerações seguintes, de ambos os casais, permaneceram na região por décadas.

Os seis inventários analisados têm pontos em comum: todos eram sesmeiros, a maioria com terras em processo de legalização, ou seja, de demarcação de limites; todos eram proprietários de escravos, num total de 49 cativos. Eles compõem uma parte da elite local, de um primeiro grupo que criou raízes profundas e que se manteve por várias gerações na região. ${ }^{58}$

Eram agricultores e criadores, principalmente de porcos, com poucas cabeças de gado e animais de carga, como mulas e bestas. Os porcos é que eram realmente numerosos. Criavam esses animais soltos no campo, indicados como "porcos do campo" ou "porcos de pasto", como no inventário de 1815: "porcos 
no campo, dezesseis cabeças avaliadas em dezesseis mil réis [16\$000]". 59 A família mais rica da amostra, de 1817, com 27 escravos, tinha "cem cabeças de porcos de pasto avaliadas em trinta e cinco mil e duzentos réis [35200]". Para a engorda, os cercavam, porque há indicação de "porcos de ceva": "quarenta cabeças de porcos de ceva em princípio de engordar avaliadas em quarenta mil réis [40\$000]". Além disso, criavam "dez carneiros avaliados em dez mil réis [10\$000]". 60 Os porcos cevados (engordados) serviam provavelmente para fazer toucinho, produto comum de Minas Gerais e de áreas adjacentes, comercializado para o mercado do Rio de Janeiro. ${ }^{61}$

Havia indicação de café, como no inventário de 1819, de Francisco Ferreira Guimarães, ferreiro, que estava em franco investimento em terras e benfeitorias. Era proprietário de duas casas na Vila, mas estava preparando terras para o plantio de café, suposição indicada pela informação genérica de árvores ou arvoredos de cafés. Era proprietário de casas de morada cobertas de telhas assobradadas, chácara e

dois ranchos cobertos de palha com arvoredos de laranjeiras e cafés, avaliado em cento e sessenta mil reis [...]. Uma sesmaria denominada Ronca Pau com títulos principiados a aprontar nas margens do Rio Negro de um a outro lado com moinho [caído] e suas respectivas pedras, casa velha [...] que foi de fabricas de mandioca, arvores de espinhos, cafés e bananeiras tudo avaliado em seiscentos mil reis. ${ }^{62}$

Entre os bens inventariados de 1820, de Sebastiana Maria, casada com Antônio de Melo Oliveira, a lavoura de café já estava estruturada, o que se conclui pela referência mais pormenorizada dos bens inventariados: seis mil pés de café plantados, "avaliados em seiscentos mil réis". Tinham também 22 "cabeças de porcos" (22\$000), seis cabeças de gado (39\$000), uma mula arreada de valor significativo (22\$000) e um macho arreado (24\$000). Era proprietária de edifícios feitos com materiais mais duradouros, como casas de vivenda cobertas de telha e esteios de braúna, além de "uma sesmaria medida e demarcada". ${ }^{63}$

Pelos bens dados a inventário entre 1815 e 1820, não há indicação de serem proprietários de terras minerais. Caso o fossem, haveria indicação no inventário, como ocorreu em inventários de outras regiões mineradoras, mesmo no século 19.64 Mas não significa que não as tivessem e as explorassem. $\bigcirc$ ouro pode ter sido uma das fontes de acumulação de capital para a formação dessas primeiras fazendas, como as dos inventariados analisados. A extração do ouro, entretanto, ultrapassou o século 18 e serviu como chamariz para ocupar a região, embora a atividade econômica possível, revelada pelos bens inventariados, tenha sido a
59. Ana Joaquina... (1815).

60. Francisca... (1817).

61. Para uma discussão sobre a lavoura de milho, os porcos e o toucinho comercializado, cf. Slenes (1985).

62. Francisco Ferreira... (1819, grifos meus).

63. Sebastiana... (1820).

64. Quando havia terras ou datas minerais, elas eram referidas em inventários: no Arraial de Guarapiranga, bispado de Mariana, em Minas Gerais, Ana Veloso do Espírito Santo possuía, em 1820, "sete datas de terras minerais citas no lugar denominado [alatanha] que partem de um lado com o Capitão Luiz Antônio Pereira, digo, Luiz Antônio de Faria, e por outro lado com Thomaz Ferreira Braga" (Ana Veloso..., 1820). 
65. Não foram encontrados os autos do processo contra o grupo nem a sentença, embora alguns especulem que possam ter sido desterrados para a província do Rio Grande de São Pedro (atual Rio Grande do Sul) (Souza, 1980, p. 79)

66. Instituto Histórico e Geográfico Brasileiro (1966). Bicentenário da transferência da capital do Estado do Brasil, da cidade do Salvador para o Rio de Janeiro. p. 89-382. Traz a transcrição da correspondência dos Vice-Reis com as autoridades portuguesas encontrada no Arquivo Histórico Ultramarino, de Lisboa. O ofício de Luís de Vasconcellos a Martinho de Mello e Castro, de 21 de setembro de 1788 , encontra-se transcrito entre as p. 333-341.

67. Ibidem, p. 338.

68. Vasconcellos e Souza (1842, p. 24). produção de alimentos, para o mercado interno e para a subsistência, com destaque para a criação de porcos, mas com o café ensaiando entrar em cena.

\section{O OURO}

Assim que os contrabandistas foram presos em 1786, e ao que tudo indica, desterrados ${ }^{65}$ o vice-rei Luís de Vasconcellos determinou a imediata ocupação das Novas Minas de Macacu ou de Cantagalo - as referências variaram, mas predominou a de Cantagalo, agora sob a chancela da Real Fazenda. As informações constam de um ofício de Luís de Vasconcellos a Martinho de Mello e Castro (secretário de Estado dos Negócios da Marinha e Ultramar do Conselho Ultramarino de Lisboa), de 21 de julho de 1788, informando o que fez na região: formou destacamentos em lugares estratégicos do sertão, com tropa, para atrapalhar os extravios; abriv estradas para o novo arraial, localizado no mesmo sítio onde os contrabandistas tinham sua "rancharia"; mandou construir casas e um armazém de mantimentos para alimentar as tropas; estabeleceu uma casa de Registro de Manifesto do Ouro, com a direção do Desembargador Intendente Geral do Ouro, Manoel Pinto da Cunha e Souza (que chegou em 2 de junho de 1787) e demais oficiais; nomeou um guarda-mor para a repartição das terras e datas minerais; concedeu, a fítulo interino, datas e sesmarias a um "maior concurso de pretendentes do que se devia esperar pela dificuldade dos caminhos, e das estradas que apenas se principiavam a abrir com bastante trabalho". 66

No mesmo ofício, informou a quantidade retirada de ouro na lavra de Sua Majestade no córrego da Lavra Velha: 5 marcos, 2 onças, 4 oitavas e 43 grãos, que representavam $408 \$ 750$ reis. Justifica o pouco rendimento da lavra por serem "estes serviços sendo feitos por gente nova e ainda pouco versada n'eles". ${ }^{67}$

Em documento datado de 1789, no qual fez relatório para seu sucessor, Luís de Vasconcellos repetiu muitas informações dadas ao secretário de estado, Martinho de Mello e Castro, no ano anterior, mas completou com outros dados:

Este mesmo Real serviço me obriga a expor a V. Exc. outras muitas particularidades relativas a este governo: e principiando pelas novas minas de Macacu, que necessitam de muitas providências, e devem merecer toda a circunspecção e cuidado de V. Exc. para se adiantarem e promoverem, como pede a sua particular importância, procurarei dar a V. Exc. as notícias mais circunstanciadas daquele estabelecimento. ${ }^{68}$ 
Disse que logo após a distribuição das datas minerais no "córrego de Cantagalo" e no "córrego das Lavras Velhas", foi constatado que eles haviam sido muito explorados pelos contrabandistas, motivo pelo qual destes terrenos somente pessoas experientes poderiam obter algum sucesso. Assim,

ignorando o modo de se fazerem os árduos serviços da mineração, e não querendo sujeitar-se a aprender aquele particular mecanismo do inspetor que ali se acha encarregado da data de S. M., por se persuadirem que podiam colher o ouro às mãos lavadas, foram alguns pouco a pouco perdendo o ânimo [...] e sem maior exame, mais do que algum que fizeram na superfície da terra, abandonaram as datas que com tanta instância haviam solicitado, dando e divulgando notícias diversas.

Para resolver o problema, pretendeu criar uma "escola", organizada da seguinte forma:

Assentei com o Desembargador Superintendente que se principiasse a dispor, com os escravos de S. M. que se achavam mais versados, um grande serviço [...], formando-se uma espécie de sociedade, para se repartirem pelos interessados as despesas da fábrica e os lucros que dela se tirarem, conforme o número das praças que tiverem [...]. Como a dita fábrica fica servindo de escola para os escravos aprenderem os diferentes usos dos ditos serviços minerais, foi encarregado de sua administração o Tenente Inspetor Joaquim José Soares, que tem bastante experiência destes trabalhos, e se acha por isso encarregado na inspeção da data de S. M. ${ }^{69}$

Esse tenente, Joaquim José Soares, experiente nos "serviços minerais", foi um dos que chegou às Novas Minas logo após a prisão do grupo contrabandista e ocupou posição de destaque na administração regional, na formação das lavouras cafeeiras e como catalizador para que homens e mulheres, oriundos de Minas Gerais, migrassem para as Novas Minas de Cantagalo. A região fornecedora de gente para Cantagalo foi, particularmente, a da freguesia de Nossa Senhora da Conceição de Guarapiranga, bispado de Mariana, a mesma Guarapiranga onde Manuel Henriques, o Mão de Luva (e seus irmãos), residia antes ou durante o garimpo ilegal do sertão de Macacu, e não deve ter sido por acaso.

Mesmo já fora do governo do Brasil, Luís de Vasconcellos continuou a se interessar pelas Novas Minas dos Sertões de Cantagalo, pedindo informações sobre seu andamento aos seus substitutos, o conde de Resende, José Luís de Castro, que governou entre 1790 e 1801, e a Fernando José de Portugal e Castro (18011806), marquês de Aguiar. Segundo o historiador José Antônio Soares de Souza, não foi encontrada uma resposta, mas em 1805, publicado na Revista do Instituto Histórico E Geográfico Brasileiro de 1849, há uma Notícias e reflexões sobre as minas de Cantagalo escritas por um autor anônimo. $\bigcirc$ documento pode ter sido 
70. Notícias... (1849, p. 523, grifos meus).

71. Carta régia (1806 apud Souza, 1980 , p. 80$)$. uma resposta do marquês de Aguiar, vice-rei do Brasil na época, a Luís de Vasconcellos, sobre a situação das Novas Minas de Cantagalo.

A se dar crédito aos dados apresentados nas Notícias, as despesas foram maiores do que as receitas para o Real Erário. Entre 1801 e 1803, foram extraídos 29 marcos, 8 onças e 42 grãos de ouro, ou 2:808\$876, que representavam o quinto. Concluo, então, que os mineradores puderam receber, em três anos, 14:044\$438 (4/5 do ouro), quantia nada desprezível, caso tenha sido dividida por poucos. Um escravo adulto, na época, valia entre $120 \$ 000$ e $150 \$ 000$. 0 valor de 14 contos poderia comprar, portanto, de 100 a 115 escravos.

A coroa portuguesa desistiu de controlar oficialmente a extração de ouro na região, não mais indicando oficiais depois da morte do último superintendente, em 1805. Os dados informados apontam para despesas crescentes e desvantajosas para os cofres reais. As despesas pelas folhas de ordenados foram: ao guarda-mor, 500\$000; ao escrivão, 500\$000; ao tesoureiro, 300\$000; ao meirinho, $300 \$ 000$ - somando, por ano, 1:600\$000; nos três anos, seriam 4:800\$000. Déficit, portanto, de 3:200\$000. Concluiu o analista que:

\footnotetext{
do que fica exposto se vê que as referidas minas não podem pagar o ordenado da sua superintendência [...]. Portanto são desnecessários nas sobreditas minas um superintendente e um guarda-mor pagos pela real fazenda [...]. E finalmente que os mineiros ou faiscadores daquele distrito sejam obrigados, sem remissão, a cultivar as sesmarias das suas datas, procurando-se, assim, quando menos, um grande excedente do trabalho daquela povoação, que aumentará o mercado desta praça e a exportação para a metrópole de mais gêneros privilegiados. [...] e seriam sempre mais úteis a S. M. e ao público as lavouras de café, açúcar, e a criação de gados nas sesmarias dos sertões de Macacu, ainda pela maior parte inculto, do que as grandes lavras de Cantagalo e de outros sítios do distrito do mesmo sertão. ${ }^{70}$
}

café, portanto, já aparece como referência para uma lavoura possível, e não deve ser por acaso: pela redação, se deduz que ele conhecia o que era produzido ou adequado na/para a região.

Em 1806 há mais notícias: o Príncipe Regente D. João mandou remeter ao Conselho Ultramarino um plano "a respeito da utilidade que se devem tirar dos melhoramentos do Sertão de Cantagalo". A resposta, em forma de memória, também não tem referência de autor: o ouro havia sido abandonado e os habitantes se dedicavam à lavoura. Contava com 28 casas "unidas" e 869 "pessoas de comunhão na boa igreja que se erigiv, com a soberana invocação do Santíssimo Sacramento de Cantagalo". 71

Ressalto que embora o ouro tenha sido extraído até início do século 19, com resultado pouco expressivo ao menos para os cofres reais, talvez não tenha sido tão 
ruim para os envolvidos, como para o tenente Joaquim José Soares, que fincou raízes em Cantagalo, e onde seus sobrinhos já adultos para lá se dirigiram, possivelmente para a exploração de lavra de ouro consorciada à produção de alimentos e à criação de porcos, opções possíveis além da nascente lavoura de café.

\section{OS BENS MATERIAIS DOS INVENTARIADOS DAS DÉCADAS DE 1810 A 1830}

Dos poucos inventários que consegui para o período de 1815 a 1820, havia alguns que demonstravam estar a fazenda em início de instalação, indicado pelos termos "novo" e por edificações rústicas. Em 1816, avaliadores foram convocados para inventariar os bens deixados pela já referida defunta Antônia Francisca Soares, tendo seu marido, Antônio Teixeira de Lemos, como inventariante.

No mês de maio, foram registrados os bens apresentados pelo viúvo, entre eles uma sesmaria de meia légua em quadra denominada Nossa Senhora da Conceição da Guia. Nela, os avaliadores indicaram haver sete escravos e uma "casa de vivenda e cozinha pegada coberta com bicas de palmitos avaliada em trinta e dois mil reis [32\$000]"; e também um "monjolo com casa coberto com as mesmas bicas, avaliado em seis mil e quatrocentos reis [6\$400]" .72

Ângelo Carrara cita as "bicas de palmito" como cobertura de edificações citadas em "papéis de mão" celebrados antes de 1840, na região de Minas Gerais. ${ }^{73}$ Também Romilda Oliveira Alves transcreve a venda de uma fazenda com casas "cobertas com bicas de palmito, moinho com essa mesma cobertura" no município de Muriaé, também em Minas, em 1840.74 Esse tipo de descrição de cobertura era raro em inventários do Sudeste, como pude constatar em minhas pesquisas. Segundo o dicionário Priberam, o termo "bicas" é usado na região de Aveiro, em Portugal, como sinônimo de "conjunto de agulhas ou folhas de pinheiro, geralmente secas; caruma". ${ }^{75}$ Aparentemente, para o Brasil, era sinônimo de "cobertura de palha", termo mais usado pelos avaliadores em inventários, pelo menos do Sudeste. ${ }^{76}$

De qualquer forma, a descrição de construções com essa cobertura, seja de bicas de palmitos, seja de palha, indicava uma edificação rústica. Até o início da década de 1830, seria de se esperar que, em uma região com fronteira recémaberta ao café, houvesse um conjunto de posses bem rústicas dos inventariados, como essas de Antônia, de 1816 . Pelo menos a rusticidade das construções e dos recheios das casas foi o que existiu para os ricos mais contidos, senhores de engenho dos Campos dos Goytacazes na capitania do Rio de Janeiro, quando se
72. Antônia... (1815, grifos meus). Tive acesso ao conjunto de inventários através da generosa doação da historiadora Keith Valéria de Oliveira Barbosa dos inventários originais digitalizados ao Centro de Memória, Pesquisa e Documentação de Cantagalo (CMPDC), História/UniRio.

73. Carrara (1999, p. 37).

74. Alves (2009, p. 89).

75. Disponível em: <https:// goo.gl/acfLSW>. Acesso em: 5 abr. 2018. Caruma tem o mesmo significado: "conjunto ou folhas de pinheiro, geralmente secas".

76. Não tenho como inferir o uso do termo "bicas de palmitos" para outras macrorregiões, mas li a referência de um paulista, em texto recheado de ironia e indignação pelas condições do "palácio" em que foi habitar, quando nomeado presidente da Província de Goiás em 1880. Joaquim de Almeida Leite Moraes, disse, descrevendo a construção: "uma sala de jantar, a melhor do palácio; a cozinha à semelhança de rancho de tropeiro; bicas de palmito recebendo as águas do telhado; soalho, em geral, podre, esburacado" (2011, p. 33). 
77. Cf. Faria (1998), principalmente o capítulo 3 .

78. Livro de assentos de batismo... (1792-1817).

79. Segundo Luís Frederico Dias Antunes (2001), é uma louça europeia que imita os desenhos orientais e os padrões decorativos da "louça da Índia”, assim denominada a porcelana da China carregada pelos navios da carreira das Índias, com produtos do oriente.

80. Francisca... (1817).

81. O sistema de concessão de sesmaria durou até 1822 , quando foi revogado. Daí em diante, somente a ocupação pura e simples foi a forma de se apropriar de terras. A Lei de Terras, de 1850 , regularizou as sesmarias e as terras ocupadas desde 1822.

82. Arquivo Nacional (Brasil). Base de dados do Judiciário. Disponível em: http://www.an.gov.br/Basedocjud/MenuDocJud/MenuDocJud.php. Acesso em: 7 abr. 2018. Agradeço a Eduardo Cavalcante a pesquisa no acervo do Arquivo Nacional sobre documentos referentes a Cantagalo. implantou a produção açucareira na primeira metade do século 18. Investiam mais em bens de produção e em mão de obra do que em casas e seus "recheios", roupas e aparatos elaborados. ${ }^{77} \mathrm{Nem}$ mesmo nas primeiras décadas do século 19, quando os senhores de engenho estavam consolidados e a economia regional apresentava solidez, os objetos dados a inventários eram sofisticados ou muito numerosos. A demonstração de riqueza e de uma vida social mais intensa, inclusive urbana, dar-se-ia somente na segunda metade do século 19.

Em Cantagalo, no entanto, não foi assim. Em 1817, somente um ano após o inventário de Antônia, realizou-se a avaliação dos bens de Francisca Rosa da Câmara, casada com o guarda-mor do rio Imbé, Manuel Vieira do Espírito Santo. O casal estava em Cantagalo pelo menos desde 1807, quando batizaram uma criança exposta em sua casa. Ele era natural de Guarapiranga, Minas Gerais. ${ }^{78}$ Possuíam 27 escravos, muitos oriundos do tráfico Atlântico, gado vacum, dezenas de bestas de carga, centenas de porcos, instrumentos de trabalhos avaliados como "em bom uso" ou "novos" e objetos dificilmente encontrados em áreas de início de povoamento, como urinóis, pratos, bacias e sopeiras de pó de pedra, ${ }^{79}$ aparelhos de café, cobertores novos, colchas de algodão, roda de fiar de jacarandá, almofada para fazer renda, espingardas novas etc. ${ }^{80}$ Era um conjunto de bens importado e relativamente sofisticado. Ou seja, em uma mesma época coexistiram fortunas que estavam em patamares diferentes, uns mais bem aquinhoados que outros, em uma região teoricamente recém-aberta ao migrante. Certos indivíduos, ou familias, tiveram acesso a heranças ou, o mais provável, a melhores condições materiais para amealhar pecúlio significativo.

Apesar da preocupação de Luís de Vasconcellos sobre o futuro do arraial que havia criado, o movimento de entrada de garimpeiros, lavradores e comerciantes em direção a Cantagalo aumentou na década de 1790, e ainda mais nas primeiras décadas do século 19. A direção da migração de Minas Gerais para os Sertões de Macacu, inaugurada pelo bando de Mão de Luva, se manteve durante muitos anos.

Entre 1787 e 1822,81 houve 59 pedidos de demarcação, 6 de confirmação, 7 de apresentação de títulos e 177 solicitações de sesmarias nas Novas Minas de Cantagalo. ${ }^{82}$ Ao que tudo indica, o ouro pode ter sido um chamariz, mas foi o café que manteve a região cobiçada por muitos e permitiu que as primeiras famílias se mantivessem por gerações na região.

Um dos que vieram de Minas Gerais e fixaram residência na localidade foi justamente o tenente Joaquim José Soares, indicado para o cargo de inspetor das datas minerais de Sua Majestade em 1787 pelo então vice-rei Luís de Vasconcellos, que também o teria incumbido de dirigir uma "sociedade" para exploração do 
ouro, como referido anteriormente. Acredito que a fortuna conquistada por Joaquim José Soares e outros na mesma época tinha como origem parte do ouro garimpado sob a chancela real.

Os dados que existem sobre o tenente são fragmentados, mas significativos. Não há registro de onde nasceu, mas foi para as Novas Minas de Cantagalo oriundo do bispado de Mariana; aparentemente foi casado, mas não tinha herdeiros necessários. ${ }^{83}$ Sempre referido como "tenente", Joaquim José Soares foi padrinho de mais de 25 crianças entre 1790 e $1816 .{ }^{84}$ Ocupou o cargo de juiz de Órfãos, conforme indicam os termos dos inventários de 1815 e 1816 e no seu próprio registro de óbito, de $1^{\circ}$ de setembro de 1817: "faleceu da vida presente [...] o tenente Joaquim José Soares, homem branco [...], sem filhos, com Fazenda junto desta Vila de Cantagalo, morador neste termo, Juiz de Órfãos". ${ }^{85}$ Solicitou a demarcação de uma sesmaria na "Paragem das Lavrinhas", em 1809,86 lugar da fazenda com o mesmo nome.

Sem herdeiros necessários, o tenente Joaquim José Soares teve seus bens partilhados entre seus quatro sobrinhos, um deles de nome José Joaquim Soares, com inventário realizado em 1832. ${ }^{87}$ Todos, tio e sobrinhos, eram residentes nos limites da vila de Cantagalo e foram indicados em diversos registros como originários de ou nascidos em Minas Gerais. $\bigcirc$ sobrinho do tenente herdou a fazenda das Lavrinhas ${ }^{88}$ e, assim como o tio, ocupou o cargo de Juiz Ordinário e de Órfãos, que exerceu pelo menos em inventário de 1824,89 e também não deixou herdeiros necessários. Por seu inventário estar muito fragmentado, não pude confirmar se era casado. ${ }^{90}$

José Joaquim Soares, o sobrinho, era possuidor de uma quantidade de bens impressionante para uma região supostamente de fronteira aberta. Proprietário de pelo menos três fazendas, das Lavrinhas, dos Passos e da Pedra Branca, tinha nelas não menos que 242 escravos. ${ }^{91}$ A esmagadora maioria dos objetos listados em seu inventário era importada, quase nada foi produzido no Brasil. Até mesmo móveis feitos com madeira nativa, como o jacarandá e o vinhático, por exemplo, eram entalhados no exterior e enviados para o Brasil. ${ }^{92}$ Os copos, cálices e aparelhos de café, licor etc., eram todos importados da Europa ou do Oriente. ${ }^{93}$

Vários de seus itens demonstravam vida social intensa: copos de cerveja, de água; "'cales' de vinho; guardanapos; aparelhos de licor, de chá, de café; garrafas de vidro, garrafões", tudo às dúzias. Vestia-se muito bem e com opções: ${ }^{94}$ "34 pares de calças de brim,95 12 jaquetas"6 de riscado,"97 15 coletes $^{98}$ de fustão, ${ }^{99} 29$ pares de meias curtas, 34 camisas, 10021 ceroulas de pano de linho, 101 chapéu branco e um preto, usados; para o social, capas $^{102}$ e casacas $^{103}$ de seda ${ }^{104}$ bordadas, lenços de seda de cor, lenços de algibeira, ${ }^{105}$ meias de seda,
83. Segundo as Ordenações filipinas (Almeida, Fernando, 1957), publicadas em 1603, os herdeiros necessários eram, na ordem, os descendentes (filhos, netos etc.), ascendentes (pais, avós etc.) e colaterais (irmãos, sobrinhos etc.), até o segundo grau de consanguinidade. Na falta deles, o herdeiro era o cofre do juizado dos Defuntos e Ausentes.

84. No assento de óbito de Joaquim José Soares, de $1^{\circ}$ de setembro de 1817 , está registrado que "faleceu de uma febre moroza [...] e consta que fez testamento" (Livro de assentos de óbito..., 1789 a 1825). Não foi possível encontrar seus testamento e inventário.

85. É referido como juiz de Órfãos nos inventários de Ana Joaquina do Amor Divino, de 1815 e de Antônia Teixeira Soares, de 1816.

86. O processo termina somente em 1817.

87. José... (1832).

88. Hoje o lugar de "Lavrinhas" é um bairro do município de Cordeiro, desmembrado do de Cantagalo em 1943.

89. Francisco Alves Filgueira... (1824).

90. Foi padrinho de algumas crianças e testemunha de casamento, mas, para homens atuando como padrinhos ou testemunhas, não havia necessidade de registrar sua condição matrimonial. Para as mulheres, era usual haver referência a sua condição matrimonial ou filiação, quando madrinhas: "solteira", "casada com", "viúva de", "filha de" etc. Não houve mulheres como testemunhas de casamento.

91. O inventário está fragmentado e faltam algumas páginas, inclusive as primeiras, as mais importantes para detalhar as relações de parentesco do falecido. 
92. Não só para o Brasil, é claro. No jornal Gazeta do Rio de Janeiro de 8 de junho de 1822 registra-se a exportação de jacarandá. Na seção "Saídas" consta: "dia 3 dito [junho de 1822] - Londres; B. [bergantim] Ing. [inglês] Melona, M. [Mestre] Thomaz Johnson, peles de lobo, açúcar e jacarandá" (Gazeta..., 1822, p. 386). O jacarandá também consta nas listas de exportações do Jornal do Commercio.

93. Uma das melhores análises sobre a transição do consumo de bens orientais (China e Índia) para o de mercadorias europeias se encontra em Freyre (2003).

94. Todas as referências destacadas estão no dicionário de Silva (1831).

95. Brim: "lençarias [nome genérico para todo tipo de tecidos] de que há muitas sortes; é grossa, para navios" (Silva, 1813, p. 301).

96. Jaqueta: "casaqueta de acolchoado ou coberta de malha de ferro, para defender o corpo" (Silva, 1813, p. 187).

97. Riscado: não existe no dicionário de Silva. Esse tipo de estampa no tecido pode ter sido criado depois, pois consta em dicionário de 1836 com o significado: "tecidos com listras ao longo de cor diferente do fundo" (Constâncio, 1836, p. 634).

98. Colete: "veste curta sem manga" (Silva, 1813, p. 414).

99. Fustão: "lençaria de linho, ou algodão, fina” (Silva, 1813, p. 71).

100. Camisa: "roupa usada por baixo, em que se vestia por cima outras" (Silva, 1813, p. 331).

101. Linho: "planta fibrosa, a qual depois de várias preparações se fia, e do fio se fazem linhas para coser, ou para se tecer lençarias de quatro pares de calças de riscado, três bodoques de riscado, casaca de pano azul, calções ${ }^{100}$ de seda". ${ }^{107}$

De roupas de cama e mesa tinha "colchas de damasco, ${ }^{108}$ toalhas de mesa finas e grossas, toalha de bretanha, ${ }^{109}$ toalhas de mão finas e grossas" 110 , tudo igualmente em grande quantidade. Havia até mesmo um jogo de gamão. ${ }^{111}$ Tabuleiros de gamão eram anunciados com destaque em periódicos em várias épocas. Na seção "vendas" do Diário do Rio de Janeiro, em 1821, se informava: "Na Rua Direita n. 99 há para vender jogos de tabolas 112 e copos de marfim para gamão, e jogos de bolas para bilhar". ${ }^{113}$ Em 1825, no Diário de Notícias do Rio de Janeiro: "Quem quiser comprar um tabuleiro de jogo de gamão com o de damas nas costas do mesmo tabuleiro, que é de jacarandá, com boas tabolas de marfim; procure na rua do Valongo perto da praia a José Egydio Roza". 114

O interessante é que havia muitas solicitações dos que o queriam comprar, como em anúncio de 1825 do Diário do Rio de Janeiro, que dizia: "Quem tiver um tabuleiro próprio para o jogo do gamão, tendo também o das damas do outro lado, e o queira vender, sendo por preço cômodo, queira anunciar por este Diário para se procurar". ${ }^{115}$

Os móveis de José Joaquim Soares eram numerosos e valiosos, como as secretárias: ${ }^{116}$ ele possuía duas, uma delas com estante; vários catres ${ }^{117}$ e camas, ${ }^{118}$ uma delas de 10 mil réis. Era proprietário, inclusive, de uma escola: "uma casa térrea onde está a escola [...] duas mesas de escola [...] três bancos compridos [...] uma cadeira de mestre com degraus [...] duas estantes ${ }^{119}$ na escola [...] uma cadeira na escola". ${ }^{120}$ Não desvendei ainda o motivo da existência de uma "escola" na região naquela época, a não ser que se relacione com a imigração suiça, da qual tratarei adiante, que previa o estabelecimento de escolas para os filhos dos imigrantes; mas era uma situação pouco usual para os descendentes de portugueses agricultores do Brasil de início do século 19.

Mesmo que esses bens listados em seu inventário não sejam para seu consumo, mas para o comércio, surpreende a existência de um mercado consumidor tão sofisticado em região interiorana e em início de produção agrícola de café para exportação. Muitos destes objetos indicam contato intenso com europeus ou com seus representantes, em particular com os suíços que para Cantagalo se dirigiram após desistirem da colônia de Nova Friburgo inaugurada em 1819, ou que vieram depois, já diretamente para Cantagalo, como foi o caso do genebrino Henri Bon, ${ }^{121}$ de que tratarei adiante.

Entre o primeiro registro do tio, Joaquim José Soares, em 1787, e o último do sobrinho, José Joaquim Soares, em 1832, a região sofreu uma enorme 
transformação. Apesar, disso, o ouro continuava a ser um forte chamariz. Em anúncio de 1829 do Jornal do Commercio, um vendedor de uma fazenda no "termo de Cantagalo", com 40 escravos, "boa casa de morada" e mais de 70 mil pés de café, propagandeava que a terra tinha "lavra de tirar ouro e licença". 122 Simbolicamente, a região ainda era conhecida pela miragem do ouro - mas foi o café, certamente, que se tornou o principal atrativo e que consolidou as fortunas oitocentistas.

\section{A CONSTRUÇÃO DA ELITE ESCRAVISTA CAFEEIRA REGIONAL}

A instalação e a expansão da cafeicultura em Cantagalo são consideradas pelos poucos que se referem ao município como tardias em relação a outras regiões cafeeiras do século 19. Eliane Vinhaes foi talvez a primeira a escrever sobre a região tendo por base uma documentação seriada, um conjunto significativo de inventários post mortem de 1850 a 1920, e afirmou ter sido a ocupação cafeeira posterior à de outras regiões do Vale do Paraíba. ${ }^{123}$ Gelsom Rozentino de Almeida também identificou a região de Cantagalo como de produção cafeeira mais recente do que a de Valença, que analisa comparativamente. ${ }^{124}$ Devo ressaltar que não era o objetivo dessas dissertações pesquisar a origem do capital financeiro e dos personagens que participaram da montagem da agricultura cafeeira regional; a problemática era relacionada ao fim da oferta de africanos pelo tráfico negreiro, finalizada legalmente em 1850, e a crise da mão de obra escrava nas décadas seguintes. ${ }^{125}$

Pelos dados que analisei, o município de Cantagalo teve implementada a lavoura cafeeira na mesma época, ou talvez até antes de outras regiões do Vale do Paraíba fluminense, como Vassouras, ${ }^{126}$ considerado o mais rico município da região no século 19, com o primeiro inventário datado de 1821, e Paraíba do Sul, cujos inventários analisados começam em 1830. ${ }^{127}$ Nessas regiões, pode ter ocorrido o mesmo que em Cantagalo, o desaparecimento dos inventários, mas continuo com a impressão de que a plantação do café ocorrev em Cantagalo em período anterior ao dessas áreas do Vale do Paraíba. O primeiro inventário para Cantagalo data de 1815, mas há indicações que sugerem a existência de cafezais em anos anteriores.

José Joaquim Soares tinha em 1832, na fazenda das Lavrinhas, seis mil pés de café velhos, 15 mil pés maduros, 14 mil quase em produção e 27 mil novos, num total de pés plantados avaliado em 8:540\$000. ${ }^{128} \mathrm{Um}$ cafezal demorava cerca de 4 a 5 anos para dar os primeiros frutos e, nos 15 a 20 anos seguintes, entrava em franca produção. Depois, ficava velho e sua colheita não era mais vantajosa. Um cafezal indicado como velho significava estar com mais de 20 anos. toda sorte" (Silva, 1813, p 229).

102. Capa: "vestidura solta, que desce dos ombros até o joelho, ou mais abaixo, e talvez até os calcanhares [...] era vestido de corte nos homens feitos, e que cingiam espada; e dos servidores do Paço" (Silva, 1813, p. 340).

103. Casaca: "vestidura, que hoje se traz por cima da veste; com botões nas mangas" (Silva, 1813, p. 355).

104. Seda: "matéria que se fia, produzida pelo bicho chamado de seda; dela se fazem sedas, ou tecidos deste nome, torçais; Torçais: cordão de vários fios de seda, ouro; servia de adorno nos vestidos antigos, hoje serve de acazear (sic) vestidos" (Silva, 1813, p. 676).

105. Algibeira: "bolso no vestido [nome genérico para roupa que cobre o corpo de homens e mulheres], onde se guarda alguma coisa" (Silva, 1813, p. 93).

106. Calções: "parte do vestuário do homem, que cobre desde a cintura até os joelhos" (Silva, 1813, p. 324).

107. José... (1832).

108. Damasco: "tecido de seda, lençaria, lã, de sorte que parte deste fica liso, e acetinado, a outra de superfície áspera, fazendo a diferença vários lavores" (Silva, 1813, p. 509).

109. Bretanha: "lençaria de linho fina que se trazia de Bretanha; a imitação dizem da lençaria desta sorte Bretanha de França, da Suécia etc." (Silva, 1813, p. 300).

110. Ibidem.

111. Gamão: "jogo de tabolas em tabuleiro, e dados" (Silva, 1813, p. 79).

112. Tabola: "peça redonda de osso, ou marfim, de que se usa para jogar gamão, as damas" (Silva, 1813, p. 748).

113. Diário... (1821a, p. 114). 
114. Diário... (1825b, p. 90).

115. Diário... (1825a, p. 50).

116. Não encontrei significado para o termo secretária como objeto, ou mobília, em dicionários publicados até a década de 1830. Todos referem a secretária como o faz Silva: "substantivo feminino de secretário, a que guarda segredos; confidente" (1813, p. 675). No dicionário Priberam há a referência: "mesa de escritório ou mesa onde se pode escrever e guardar documentos; papeleira". Disponível em: <https://goo.gl/EcVQrH>. Acesso em: 5 abr. 2018.

117. Catre: "leito de pés baixos, de armar, com lona na parte onde se lança o corpo" (Silva, 1813, p. 363).

118. Cama: "leito de dormir, com o aparelho pertencente para isso" (Silva, 1813, p. 328).

119. Estante: "peças de madeira, em que se põem os livros para se lerem" (Silva, 1813, p. 772).

120. José... (1832).

121. Cf. Bon (2006).

122. Jornal... (1829, p. 2).

123. Cf. Vinhaes (1992).

124. Cf. Almeida, Gelsom (1995).

125. Esses estudos fizeram parte de uma tendência historiográfica das décadas de 1980 e 1990 que se caracterizaram pela análise exaustiva de fontes seriadas, como inventários, registros paroquiais de terras da década de 1850 e registros de escrituras notariais, orientadas ou inspiradas pela historiadora Maria Yedda Linhares, para estudar os complexos agrários regionais.
A fazenda teria, então, começado a produzir café em torno de 1810, um ano depois que o tio, Joaquim José, antigo proprietário, solicitou sesmaria na "paragem das Lavrinhas". ${ }^{129}$ Foi o tio, então, quem teria dado início à lavoura cafeeira e escravista em suas terras, no começo do século 19.

Outra referência de que a lavoura cafeeira já era um empreendimento de certo vulto na década de 1810, em Cantagalo, está em um anúncio publicado na Gazeta do Rio de Janeiro, de 30 de novembro de 1814 :

Quem quiser comprar uma sesmaria de meia légua de terras em quadra, no distrito de Canta Gallo, com provisão de medição e demarcação, com dois mil pés de café, com um grande laranjal, e bananal, com casas cobertas de palha, com paiol, e uma cerca de espinho, que faz ataque a maior parte do pasto: fale com João Francisco dos Santos, morador na rua das Violas, na loja de Caldeireiro de Joaquim Alves de Oliveira, que fará aviso ao dono, que é Antônio José de Campos, que presentemente está assistindo no Engenho da Entrada, do Tenente Coronel Francisco Ferreira, nas Cachoeiras de Macacu. ${ }^{130}$

Sobreviveu somente um inventário da década de 1820, infelizmente. Em 1824, Francisco Alves Filgueira Marra teve os bens inventariados após sua morte. Era casado com Maria Vieira da Câmara, filha de Francisca Rosa da Câmara, cujo inventário de 1817 foi analisado anteriormente. Maria Vieira foi denominada "dona". O casal tinha "um cafezal de oito mil pés de café, laranjeiras e mais arvoredos de espinho avaliado em um conto e trezentos mil réis [...] setenta e oito arrobas de café [colhido] avaliado em cento e noventa e nove mil e seiscentos e oitenta réis", a Fazenda do Penedo, originária de sesmaria, com "umas casas de vivendas, monjolo, moinho, paiol"; além de "casas cobertas de telha" na Vila de Cantagalo. Possuía "quarenta cabeças de porcos de pasto entre porcos e leitões". O milho aparece em praticamente todos os inventários desse período, usualmente destinado à engorda de porcos, como neste, de Francisco: "uma derrubada de quatro alqueires de milho avaliada em cento e noventa e seis mil réis; outra dita de seis alqueires avaliada em oitenta e quatro mil réis". ${ }^{131}$ Tinham 27 escravos. Este é o único inventário para a década de 1820, mas tudo leva a crer que foi nesta década que o café se consolidou como principal atividade econômica da região.

No início da década de 1830, o café passou a ocupar o primeiro lugar na pauta de exportações do Brasil, ultrapassando o açúcar. ${ }^{132}$ Não consegui dados que confirmem a procedência deste café, mas certamente Cantagalo era uma das origens. Nos Apontamentos estatísticos da Vila de São Pedro de Cantagalo, de 1828, a região era descrita como sendo formada por terreno "montuoso" e localizada a oeste da Serra dos Órgãos, a 30 léguas da capital do Império. Tinha cerca de 1.800 habitantes e 2.700 escravos, distribuídos em 450 fogos (domicílios), com exportação anual de 100 mil arrobas de café e algum toucinho. 100 mil 
arrobas equivalem a 1.500 toneladas de café; considerando que um pé de café produz, em média, 0,5 kg de café já beneficiado, ou seja, já seco, a região tinha pelo menos três milhões de pés de café em 1828. Tinha 27 engenhos de açúcar, 17 tabernas, três lojas de fazenda, uma estalagem, uma padaria e duas lavras de ouro. Importou escravos, ferro, aço, vinho, fazendas secas, farinha de trigo, bestas, boiadas e açúcar. ${ }^{133}$ Caso esses dados sejam fidedignos, e nada leva a crer o contrário, era uma região em franca expansão econômica.

Nos anos seguintes, aumentou a quantidade e representatividade dos cafezais e do café colhido no conjunto de bens inventariados. Os porcos foram relegados a segundo plano, embora nunca tenham deixado de existir, como se constata no inventário de Antônio Rodrigues de Moraes, aberto em 1833. Era proprietário de "um cafezal com noventa mil pés já dando; um dito com oito mil pés [...] cinco mil quinhentos e sessenta e oito alqueires de café seco". As benfeitorias de serviço se aprimoraram: "uma casa de guardar café de telha $150 \$ 000$ [...] uma casa com 120 palmos para porcos, e bezerros de madeira 80\$000; uma seva no pasto 20\$000". Mas a produção de alimentos e as criações de gado e de porcos continuavam: "noventa e seis cabeças de gado = entre grandes e pequenos [...] um pomar de laranjeiras 40\$000; setenta e três porcos de pasto 1600 - $116 \$ 800$; oito capados na seva 6500 - 52\$000; trezentos alqueires de milho 240\$000; dez alqueires de milho, digo, feijão 10\$000". ${ }^{134}$

As famílias que vieram de Minas Gerais para as Novas Minas de Cantagalo, de locais com extração aurífera em declínio, como era o caso da freguesia de Nossa Senhora da Conceição de Guarapiranga, eram experientes no manejo e na distribuição de produtos do setor de alimentos para o mercado interno. ${ }^{135}$ A região consorciava, desde sua ocupação na década de 1710, as lides auríferas à produção de alimentos, o que continuaria pelo século 18 adentro. ${ }^{136}$

Segundo Marieta de Moraes Ferreira, Antônio foi o quarto filho do casal Antônio de Moraes Coutinho e Maria Felizarda de Sant'Ana, nascido em Nossa Senhora da Conceição do Campo dos Carijós (hoje município de Conselheiro Lafaiete), ${ }^{137}$ bispado de Mariana, Minas Gerais, em 1793. Foi para Cantagalo antes de 1820, pois neste ano se casou com Basília Rosa da Silva, nascida em Cantagalo, em 1802. Os pais de Basília eram de uma das famílias que tiveram filhos no ainda Arraial das Novas Minas de Cantagalo, antes de 1800. Descortinando a origem familiar do lado materno, Marieta de Moraes identificou os ancestrais de Basília: sua avó, Ana da Conceição, era "parda forra". ${ }^{138} \mathrm{Seu}$ pai, João Baptista Rodrigues Franco, estava em Cantagalo desde 1787, e solicitou, como todos que lá estavam na mesma época, uma sesmaria, em 1793.
126. Os dados pesquisados sobre Vassouras, uma das mais bem estudadas regiões do Vale do Paraíba Fluminense, no século XIX, são de 1821 em diante. Cf. Salles (2008), que analisou 729 inventários de 1821 a 1880 .

127. Fragoso (2013, p. 11).

128. A avaliação era de 200 reis cada pé de café dos 15 mil em produção, 150 reis os quase em franca produção dos 14 mil, 100 reis cada um dos 27 mil pés novos e 100 mil reis cada pé dos seis mil velhos. Cf. José... (1832).

129. Joaquim José Soares, o tio, aparece anteriormente nos documentos do Arquivo Nacional: é referido como ex-proprietário de uma sesmaria localizada nas Novas Minas de Cantagalo, entre 1792 e 1819 , cujo novo solicitante era José Gomes de Moura que, como ele, estava há anos na região.

130. Gazeta... (1814, p. 4, grifos meus).

131. Francisco Alves Filgueira Marra... (1820).

132. Cf. Eisenberg (1977). Na década de 1820, o café representava quase $20 \%$ do valor das exportações; na de 1830 , passou para $43,8 \%$ e a proporção só aumentou.

133. Apontamentos... (1828 apud Souza, 1980, p. 83-84). 134. Antônio... (1833).

135. Guarapiranga, especialmente, foi uma das primeiras regiões auríferas de Minas Gerais. Segundo Renato Pinto Venâncio (1997), os veios auríferos foram descobertos em meados da década de 1710 , e o arraial de Guarapiranga ocupou o sexto lugar entre os dezenove núcleos de extração mineral em 1721, elevado à categoria de freguesia logo depois, em 1824. 
136. Há inúmeras dissertações e teses sobre Guarapiranga, e pretendo futuramente relacionar com maior propriedade os motivos que fizeram com que a população dessa freguesia migrasse para o que se tornou a vila de São Pedro de Cantagalo pelo século XIX adentro.

137. Local próximo à freguesia de Guarapiranga e com quadro econômico similar, em fins do século XVIII.

138. Ferreira (2008, p. 102). 139. Antônio... (1833).

140. Jornal... (1828a, p. 3, 1828 b, p. 3, 1828c, p. 4).

141. Marreto (2015, p. 3-4).

142. José... (1832).
No inventário do casal Antônio e Basília há a transcrição de uma sociedade realizada entre eles e Antônio Clemente Pinto, o futuro barão de Nova Friburgo, assinada em 16 de agosto de 1826, com prazo de validade de oito anos, referente à fazenda de Santa Maria do Rio Grande. Antônio morreu antes do fim do prazo, assassinado. Antônio Clemente Pinto foi a Cantagalo, assinando vários documentos inclusos no processo, e o resultado foi o espólio do inventariado ficar devedor ao comerciante, ${ }^{139}$ principalmente por conta dos 59 escravos comprados para a fazenda de Macabu, não incluída na sociedade. Destes, 38 homens adultos foram indicados como de "Moçambique" ou "Inhambane", 13 mulheres com as mesmas referências, e sete crianças "crioulas", filhas de cinco de suas escravas.

Antônio Clemente Pinto estava ligado diretamente ao tráfico de escravos com Moçambique, na África. No Jornal do Commercio da década de 1820, ele aparece várias vezes como responsável por receber escravos, na seção intitulada "O alvissareiro mor": em 2 de janeiro de 1828, registrou-se: "Bergantim n. 28 de Quilimane: carregou 504 escravos, mortos 14, a Antônio Clemente Pinto"; em 4 de março 1828, "Quilemane Bergantin no. Hercules 58, carregou 592 escravos, destes morreram 42, a Antonio Clemente Pinto"; em 12 dezembro 1828, "Quilimane Barca Nacional Amizade em 60 dias, carregou 549 escravos, a Antônio Clemente Pinto Pereira". ${ }^{140}$

Rodrigo Marins Marreto encontrou mais informações sobre o tráfico a cargo de Antônio Clemente Pinto no Diário do Rio de Janeiro, em seção de mesmo nome, "O alvissareiro mor". Em 1827 "carregou 416 escravos, mortos 2, a Antônio Clemente Pinto". Mas há mais uma indicação citada por Marreto, na Gazeta do Rio de Janeiro, também de março, de que ele recebeu 520 cativos, e morreram 85. ${ }^{141} \bigcirc$ total das importações de escravizados oriundos de Moçambique para o Rio de Janeiro sob a responsabilidade de Antônio Clemente Pinto, entre 1827 e 1828, foi de 2.581 pessoas, morrendo, no trajeto, 143 delas.

Para colocar esses escravos, Antônio Clemente Pinto realizou sociedades com sesmeiros residentes e produtores de café em Cantagalo; Antônio Rodrigues de Moraes foi apenas um deles. Outra sociedade identificada em inventário foi com José Joaquim Soares, o sobrinho do tenente Joaquim José Soares, como consta do recibo assinado pelo finado em $1^{\circ}$ de junho de 1826. Antônio Clemente Pinto atuou inclusive como avaliador dos escravos neste inventário, ao qual estava ligado por uma sociedade denominada por ele de "Pinto e Soares". ${ }^{142}$

Não é meu objetivo analisar o procedimento do futuro barão de Nova Friburgo, de seu sucesso ou insucesso nesses acordos, mas sim da outra parte da sociedade, a dos residentes. Clemente Pinto morava no Rio de Janeiro, nunca morou em Cantagalo, nem criou por lá relações de parentesco, como o de 
compadrio, por exemplo. ${ }^{143}$ Mas, naquele momento, ainda na década de 1830, foi preciso que ele próprio estivesse presente no local para atuar como avaliador dos escravos do espólio de José Joaquim Soares, em 1832, relativo a um montante de seis contos de reis, quantia irrisória se comparada à que angariou nos decênios seguintes, ou para fazer declarações em presença do Juiz de Órfãos, no inventário de Antônio Rodrigues de Moraes, de 1833. A impressão é a de que ele estava experimentando investimentos, e não poderia legar a representantes o controle de suas sociedades, pelo menos naquele momento inicial. Ele próprio solicitou sesmarias em Cantagalo, em processo com datas limites de 1819 e 1820.

Parece que Antônio Rodrigues de Moraes teve sucesso, porque foi por conta de seus empreendimentos nas terras de Cantagalo que conseguiu o prestígio social, embora tenha sido o comércio de escravos a base de sua fortuna. $\bigcirc$ motivo de Antônio Clemente Pinto ter investido seus grossos recursos em Cantagalo, e não em outra região do Vale do Paraíba fluminense, talvez tenha sido por conta de seu tio, o português João Clemente Pinto, que conhecia a região. João trilhou o mesmo percurso que outros: nascido em Portugal, estava em Minas Gerais em 1804, o que se constata por uma solicitação que faz neste ano para ser confirmado no posto de alferes da Companhia de Ordenança do distrito da Capela de São Roque de Canastra, termo da Vila de São Bento de Tamanduá (hoje município de Itapecerica). ${ }^{144}$ Poucos anos depois, entretanto, estava em Cantagalo, onde solicitou uma sesmaria em 1809, com processo terminado em 1812. João Clemente Pinto recebeu as terras situadas no Ribeirão então batizado por ele de Nossa Senhora das Areias:

João Clemente Pinto pede por Sesmaria meia légua de terra em quadro onde tem derrubado matas no Ribeirão de Na. Sa das Áreas, que faz barra no Rio Paraíba cujo córrego sendo desconhecido por este nome por ser a primeira vez que assim se denomina me foi preciso proceder nas precisas indagações, pelas quais vim no conhecimento de estar devoluta a terra, que pede no dito Ribeirão, onde me consta ter derrubado alguns Matos para cultivar e plantar. Arraial de Cantagalo, vinte de setembro de 1812. Vicente José Franco. ${ }^{145}$

Avalio que a rapidez com que a cafeicultura escravista de grande porte foi montada em Cantagalo tem relação com a região já ser ocupada com produção de alimentos, situação bem mais confortável para os empreendimentos do que aquelas que estavam cobertas de matas e de indígenas. Os residentes vieram de famílias já consolidadas em outras áreas, também de extração rarefeita de ouro e de criação de animais, como era o caso de Guarapiranga e de outras freguesias do Bispado de Mariana. Por outro lado, houve o interesse de comerciantes de grosso trato ligados ao comércio de escravizados em investirem no café da região. O resultado foi a criação de grandes unidades agrícolas escravistas administradas
143. Identifiquei a presença de Antônio Clemente Pinto atuando como testemunha em casamento de um casal de libertos, em 1835, e de seus sobrinhos, Francisco Clemente Pinto e Bernardo Clemente Pinto, como testemunhas de um casamento de noivos suíços, em 1840. A família Clemente Pinto não batizou seus filhos, não se casou e nem estabeleceu relações de compadrio na matriz do Santíssimo Sacramento de Cantagalo no século XIX. Pode ser que, por terem oratórios e capelas particulares, esses registros estejam em outros fundos documentais. Cf. Livros de assentos de batizado e casamento.

144. Requerimento... (1804).

145. Sesmaria... (1809-1812). 
146. João... (1820).

147. Sobre os motivos que levaram à saída de milhares de pessoas da suíça, na época, cf. Bon (2004).

148. Bon (2004, p. 451-452).

149. Documentação particular de Henri Bon e documentos do Archives Fédérales Suisses, em Bon (2006, p. 308-319).

150. Idem (2004, p. 452). pelos antigos residentes ou por assalariados contratados pelos proprietários, os comerciantes absenteístas. No meio desse processo, levas de europeus, principalmente suíços, se dirigiram para a região.

\section{OS SUÍÇOS EM CANTAGALO}

Em 1832 foi aberto o inventário de João José Foli (ou Foly, Folly, como grafado nos registros paroquiais), casado com Maria [ilegível]. João José Folly teve pelo menos quatro filhos casando em Cantagalo nas décadas de 1820 e 1830. A família tinha somente um escravo, mas oriundo do tráfico atlântico: Francisco, nação Benguela. Os bens eram poucos, constando de instrumentos de trabalho (enxadas, foices, machado etc.), nove cabeças de gado, dois cavalos, poucas roupas e utensílios domésticos, como panelas de ferro, caçarolas, pratos e alguns talheres. Nitidamente estavam em implantação da lavoura cafeeira: seis mil pés de café plantados e quinze arrobas de "café muito inferior". 146

A entrada em grande escala de imigrantes suíços na província do Rio de Janeiro foi resultado do acordo ${ }^{147}$ assinado em 1818 entre o rei D. João VI e o suíço Sebastien Nicolas Gachet, no qual se estabeleceu a criação de uma colônia denominada Nova Friburgo, com terras desmembradas da jurisdição da Vila de Cantagalo para a instalação dos colonos suíços de religião católica. Mais de 1.500 suíços chegaram ao Brasil em 1819, entre eles João José Folly e sua família, que perdeu seis de seus onze filhos na travessia. ${ }^{148}$

A imigração não parou por aí. Durante os anos seguintes, muitos suíços, e nem sempre católicos, se encaminharam espontaneamente para o Brasil, embora não necessariamente para a colônia de Nova Friburgo, onde, na realidade, poucos permaneceram. Dirigiram-se para outras paragens, "de terras quentes", em comparação às terras de clima frio de Nova Friburgo; as do Vale do Paraíba, principalmente para Cantagalo, que já tinha lavouras de café. Cantagalo chegou a ter mais suíços que Nova Friburgo, tantos que a Vila foi escolhida para ser a sede de um vice-consulado suíço em 1861 - que durou até 1865 -149 e não a vila de Nova Friburgo.

João José Foli (na grafia brasileira), sua mulher e filhos foram uma das primeiras famílias a chegar ao Brasil, em 1819, vindas da Suíça para Nova Friburgo. Também foi uma das primeiras a abandonar seu lote de terras, pois estavam em Cantagalo já em 1824, onde compraram uma posse de terras no "córrego do Tejuco". ${ }^{150}$ Como João José, tornarem-se cafeicultores escravistas foi o 
objetivo de muitos desses suíços, conforme se depreende de uma carta publicada em 1826 por um deles, que assina somente como Levieux, no qual desabafa sobre o que considerou como péssimas condições a que os colonos foram obrigados a aceitar quando da chegada à colônia de Nova Friburgo em 1819, e as soluções que encontraram para resolver seus problemas nos cinco anos seguintes.

Em 16 de janeiro de 1826, o jornal $\bigcirc$ Spectador Brasileiro publicou a carta de Levieux (datada de 15 de dezembro de 1825), na qual comenta uma matéria que criticava os gastos do governo com a colonização estrangeira. ${ }^{151} \mathrm{Na}$ referida matéria de novembro de 1825, o autor, que presumo ser o editor do jornal, ${ }^{152}$ avaliava que:

O dinheiro que o Governo gasta em estabelecer Colônias, as quais nenhum grão de café, nenhuma libra de açúcar nem qualquer outro produto tem por ora entregado ao comércio, mil vezes melhor empregado seria em diminuir o peso dos impostos que carregam a importação. ${ }^{153}$

Em resposta, Levieux argumentou:

Vós dizeis Sr., que os Colonos ainda não produziram uma só libra de açúcar etc. Seguir-se-ia disto, que não se poderia considerar membro útil da sociedade, que não haveria para os primeiros Colonos algum outro meio de compensar as despesas primárias do seu estabelecimento, do que produzindo gêneros de exportação! ${ }^{154}$

Levieux pretendeu demonstrar que, para se chegar a produzir gêneros "coloniais", ou "tropicais", os suíços precisavam antes produzir alimentos fundamentais para a sobrevivência - fato que o autor da crítica parece ignorar. Os suíços, porém, já estavam plantando cafezais, pois "eles têm preparado viveiros, os quais prometem que dentro de poucos anos, terão para mais de 600.000 pés de café, principalmente no distrito de Cantagallo, e nas margens do Macaé". Eram as terras denominada por ele de "clima quente", em comparação às que para onde foram levados. ${ }^{155}$

Levieux resumiu o que os suíços realizaram em pouco mais de cinco anos, inclusive dando ênfase à produção de alimentos para o mercado interno, mas tudo leva a crer, por suas palavras, que o objetivo maior dos imigrantes seria a produção de café.

Exportam já daqui para o Porto das Caixas capados cevados, ${ }^{156}$ muitas galinhas, muitas batatas, sem falar de outros gêneros acessórios. [...] desde então quase metade da sua população [suiça] ocupa-se vantajosamente da cultura do café; se eles ainda não têm plantado mais de 250.000 árvores, é por que a sua população se compõe de mais crianças em idade baixa do que de indivíduos com forças para derrubadas de matos virgens. [...] É bem verdade que os que já colhem café, não o conduzem ao mercado do Rio de Janeiro, porque ainda thes convêm mais vendê-lo aos compradores de comissão em Cantagalo, e em Nova Friburgo, que por sua conta o fazem conduzir para ali. ${ }^{157}$
151. Deve-se ressaltar a imigração suíça, em 1819 , e a alemã, em 1824, para a região de Nova Friburgo, na província do Rio de Janeiro.

152. Creio que se trata do editor do jornal, pois não há assinatura, somente a informação, ao final: "continua ...".

153. "Sobre a agricultura no Brasil: continuação do $\mathrm{n}^{\circ} 198$ de 11 de novembro", em O Spectador.. (1825, p. 2).

154. Seção de correspondências do jornal (Ibidem, p. 3-4).

155. Ibidem, p. 3-4.

156. Porcos gordos.

157. O Spectador... (1825, p. 3-4). 
158. Bon (2006, p. 38).

159. Ibidem, p. 46.
Informa também que a imigração suíça não dependia mais do governo, pois muitos estavam vindo para o Brasil por conta própria, como no caso que descrevo a seguir.

\section{TROCAS CULTURAIS: RURALIZAÇÃO DE EUROPEUS E EUROPEIZAÇÃO DE BRASILEIROS}

Um dos colonos que viajou por conta própria e chegou ao Brasil no ano de 1826 foi o genebrino Henri Bon, de família calvinista e língua francesa, que deixou centenas de manuscritos em sua fazenda Boa Vista, em Cantagalo, recuperados e analisados pelo historiador Henrique Bon. Os mais de 400 documentos eram compostos de cópias das cartas que enviava ao irmão (Jules Bon) em Genebra, das cartas desse irmão e demais parentes e amigos a ele, alguns de genebrinos também residentes no Brasil, recibos, gravuras, registros de casamentos, nascimentos e mortes etc. Henrique Bon desvendou a origem da família e o cotidiano desse imigrante que se transformou em um cafeicultor escravista nas terras de Cantagalo entre os anos de 1827 e 1878. Filho de um relojoeiro, Henri era de família razoavelmente abastada e de posição confortável na sociedade suíça, mas que muito sofreu com a crise econômica de 1816 e 1817, época pós-napoleônica.

Com a idade de 20 anos, decidiu migrar para o Brasil. Conforme carta enviada ao irmão, resumiu sua vida: partiu de Genebra em 20 de maio de 1826, embarcou em 30 de maio do mesmo e chegou ao Rio de Janeiro em 30 de julho do mesmo ano. Foi direto para Cantagalo, onde se estabeleceu no lugar denominado Penna llocalidade então pertencente a Cantagalo e, agora, ao município de Cordeirol e se casou em 17 de fevereiro de 1828. ${ }^{158}$

Na Penna havia uma quantidade significativa de suíços. Foi com a filha de um deles que se casou, adquiriu terras, iniciou o plantio de café e comprou escravos. Pouco mais de dois anos depois de sua chegada ao Brasil, aparentemente Henri Bon estava confortável na posição de senhor de escravos, tanto que escreveu ao irmão em agosto de 1828:

o meu negro não chegou a perder-se, entretanto ainda não posso felicitar-me por minha escolha, uma vez que há três semanas atrás ele teve a ideia de fugir com um amigo seu (por que dei uma bofetada a um deles - preço de sua desobediência). $O$ projeto deles era partir para suas terras no Congo, mas como estes senhores não tinham Passaportes, felizmente foram impedidos por um vizinho, isto não impediu que eu passasse 24 horas de inquietação, não pelo medo de perdêtos para sempre, mas pela ausência deles por algum tempo na época de maior trabalho. ${ }^{159}$ 
Em carta a um amigo, datada de 1828, informa que tem "dois mil pés de café dando frutos", perdeu um escravo, mas comprou outro e mais uma chácara vizinha à sua com dinheiro de empréstimo. Também diz que produzia quase todo o necessário para viver, menos sal e roupas. Ao que tudo indica, o suíço havia se adequado à vida do Brasil rural, mesmo demonstrando estranheza em alguns aspectos:

Estou no parágrafo em que me dizes que são oito horas da noite, eu creio que deve ser mais ou menos esta hora agora, já que meu relógio parou desde que estou neste país vais pensar que estou jantando, mas já acabei, infelizmente a diferença é grande e o pedaço de mandioca substitui o bom pão feito em casa, uma omelete com farinha de milho em vez do bom assado de carneiro e a salada romana, e enfim, água fresca das montanhas em vez de vinho de nossas adegas. ${ }^{160}$

Não usava mais sapatos, só aos domingos, e para que o amigo não ficasse achando que se sentia mal por isso, escreveu:

Quanto aos sapatos, nós quase não os usamos, pois fica-se com os pés descalços, menos nos domingos. Tão penoso quanto possa parecer este tipo de vida, a gente acaba se acostumando e te asseguro que acho os trabalhos agrícolas menos penosos do que ir de certa forma mendigar as boas graças e a convivência com as detestáveis tecelagens. ${ }^{161}$

Deu notícia de vários genebrinos conhecidos, alguns com sérias dificuldades financeiras; outros, abastados, como os irmãos Porchat, com quem se encontrou algumas vezes. Estes tinham chegado ao Brasil em 1821 e foram para a cidade de Santos, na província de São Paulo, onde ocuparam ou adquiriram a itha que hoje leva seu nome, Iha Porchat. Em suma, Henri Bon se relacionava com suiços e outros imigrantes (franceses, italianos e alemães) vizinhos e, por meio de cartas, com parentes e amigos na Suíça. Foi provavelmente por cartas dos suíços chegados ao Brasil antes dele que o imigrante teve notícias sobre as boas perspectivas de Cantagalo, já que não parou no porto do Rio de Janeiro: foi direto estabelecer-se na vila.

Por outro lado, a correspondência com um amigo genebrino residente no Rio de Janeiro demonstra a forma como pode ter se dado entrada usual dos artigos europeus nas terras de Cantagalo. Havia imigrantes suíços de variados níveis de fortuna, alguns com famílias muito pobres, auxiliados por associações beneficentes, existentes desde 1821 em Nova Friburgo, 162 mas um grupo expressivo manteve o comércio com a Europa através de seus familiares lá residentes, como foi o caso do amigo de Henri Bon, Maurice Dunant, tratado adiante.

Os suiços não eram necessariamente consumidores dos caros produtos europeus, mas funcionaram como intermediários entre as firmas ou vendedores europeus e os fazendeiros locais. Um exemplo é a oferta do seu irmão, Jules Bon 
163. Idem, 2006, p. 82.

164. Ibidem, p. 155.

165. Ibidem, p. 294.

166. Além de Maurice Dunant, Henrique Bon citou Louis Meyrat, Gretillat e Jacques Gillierd.

167. Bon (2006, p. 160).

168. Ibidem, p. 114. (morador em Genebra), para Henri vender relógios. Ele chegou em 1826, com seu relógio que "parou desde que estou neste país" em uma época em que pouquíssimos no Brasil tinham relógio. Nos anos seguintes, seu irmão sugeriu que ele revendesse relógios, supondo que estava mal, financeiramente, ao que respondeu: "a ideia de fazer de um agricultor um vendedor de relógios. Eu te agradeço sinceramente [...] [mas] estou decidido a continuar agricultor". ${ }^{163}$ Há referência também a amigos suíços que realmente se dedicavam a vender relógios, como Trot, relojoeiro, que teve problemas financeiros, induzindo ainda mais Henri Bon a permanecer como agricultor.

Os relógios, aliás, foram assunto constante nas correspondências do suíço com seus parentes e amigos, tanto da Europa quanto do Brasil. Os presentes dados por uma tia a seus sobrinhos, filhos de Henri Bon, foram relógios de bolso, em 1855. Segundo Bon, foram quatro relógios presenteados a sua esposa e filhos. Dois filhos mais velhos (Jules e Georges) já os tinham, "mas arregalaram os olhos diante de tamanha riqueza". ${ }^{164}$

Nos inventários existentes para Cantagalo até 1820 não há referência a relógios, mas nos seguintes eles estão quase sempre presentes, com os tipos assim descritos: relógio "grande de mesa", "de cobre antigo dourado", "de ouro francês", "de parede e caixa", "pequeno", "de ouro" etc. (Figura 4)

Jules Bon, o irmão, viajava por diversos países em atividades comerciais, tinha uma fábrica de relógios e uma ourivesaria. ${ }^{165} \bigcirc$ genebrino Maurice Dunant, com quem Henri se correspondeu durante anos, era um dentre vários intermediários residentes no Rio de Janeiro a se encarregar de receber e enviar cartas de um e outro lado do Atlântico, como também mercadorias europeias de um lado, e de café, de outro. ${ }^{166}$ Dunant fazia frequentes viagens à Europa, se encontrando até mesmo com o irmão de Henri Bon, em Genebra - ${ }^{167}$ era um elo de ligação entre vários suíços de ambos os continentes, dando sempre notícia de muitos (Figura 5).

As viagens de certo grupo de imigrantes radicados no Brasil à Europa, talvez a negócios, eram frequentes, como no caso de Monsieur Boucher - francês amigo e vizinho de Henri Bon em Cantagalo -, que viajou com sua esposa à Europa, onde se encontrou com Jules, irmão de Bon, em Genebra, em junho de 1842. ${ }^{168}$ Segundo Jules, Boucher ficou três dias em Genebra, iriam a Friburgo, à Itália, voltariam a Paris e retornariam em maio (de 1843) para o Brasil. Henri havia pedido que o irmão comprasse prataria para ser revendida no Brasil, que deveria ser encaminhada pelo amigo Boucher. Henri não era e nem queria ser comerciante, mas poderia aproveitar o contato com a família na Europa para obter algum lucro na venda de mercadorias bastante cobiçadas pelos enriquecidos locais e remetidas pelos amigos, não necessariamente suíços, que iam frequentemente à Europa. Nesse ano, Henri já era proprietário de nove escravos. 


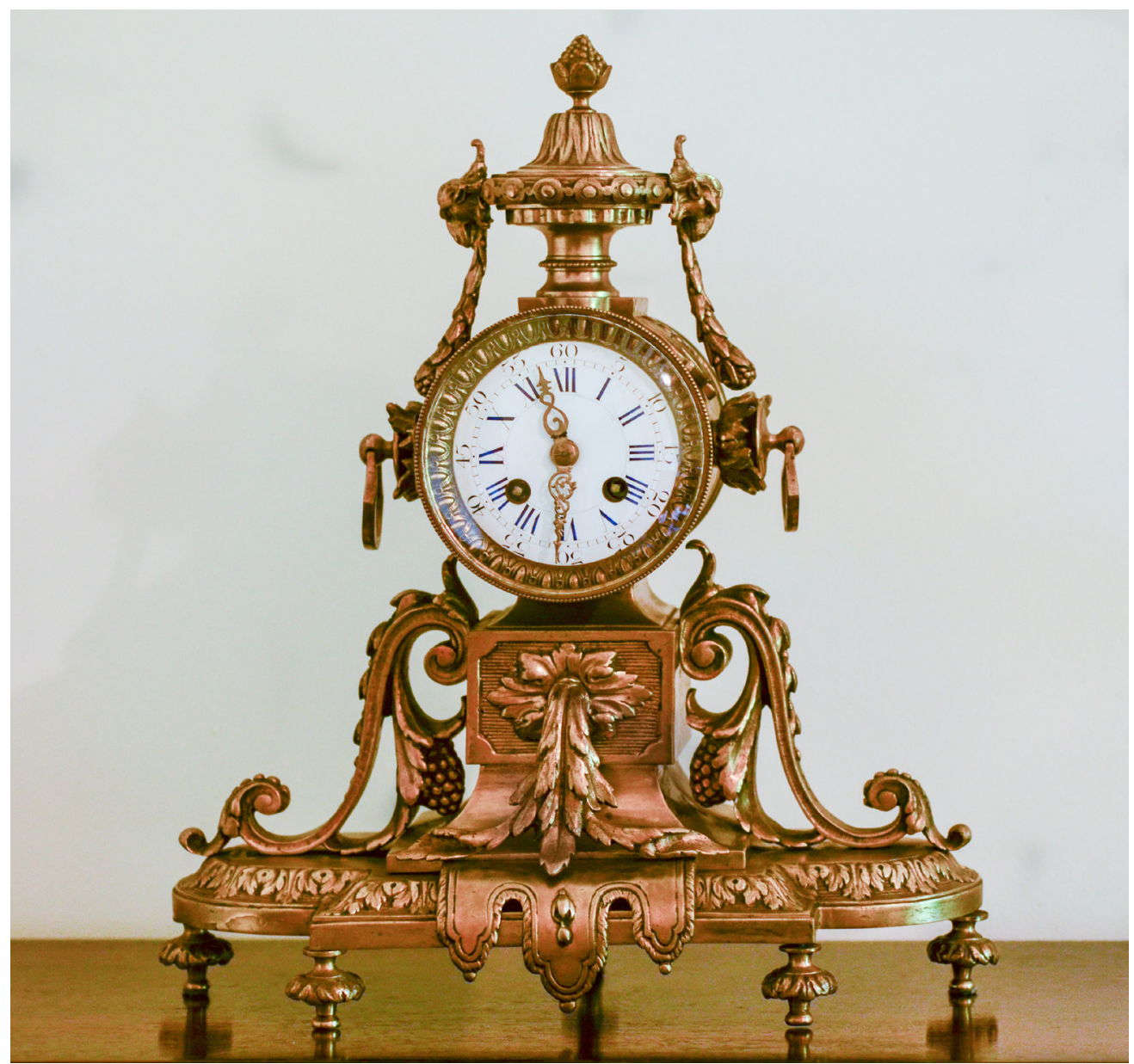

169. Não se sabe a data de sua aquisição, mas ele pertenceu ao primeiro Barão de Nova Friburgo, Antônio Clemente Pinto, comprado provavelmente de um comerciante europeu, e fazia parte dos objetos de sua Fazenda das Areias, localizada à margem do Ribeirão batizado por seu tio, João Clemente Pinto, de Nossa Senhora das Areias, em 1809.

170. Ibidem, p. 145 , grifos meus.

Figura 4 - Relógio de mesa francês do século 19 em bronze ormolu, estilo Luís XV. ${ }^{169}$ Foto: Conceição Franco. Fonte: Coleção Álvaro Sagulo, Acervo da Fazenda São Clemente, Cantagalo.

Exemplo do que afirmo é que Henri Bon foi à Suíça em 1855, mas antes passou por Paris, para compras, remetendo as mercadorias através da firma de Louis Meyrat, em Porto das Caixas, porto fluvial de grande movimento no interior do Recôncavo da Guanabara (hoje faz parte do município de Itaboraí, no Rio de Janeiro). ${ }^{170}$ Entre es mercadorias constavam várias dúzias de colheres e garfos de metal galvanizado, livros, vidros de conserva, sementes, meias, lenços de seda para algibeira, cortes de tecido etc.

Havia muitas firmas encabeçadas por estrangeiros residentes no Brasil, as responsáveis pela maior parte dos produtos importados vendidos no Brasil, sem dúvida, mas as mercadorias remetidas da Europa por Henri Bon estavam em listas que indicavam outros habitantes de Cantagalo e de Nova Friburgo que também as recebiam, demonstrando que o procedimento - revenda de mercadorias por parte de estrangeiros residentes no interior do Brasil - era comum. Henri Bon não 
171. Tradução: "Rio de Janeiro, 12 de novembro de 1859. Monsieur Henri Bon no Taquaral. Compatriota e amigo. Confirmo-vos minha última carta de 30 de outubro findo, remeto-vos hoje os jornais de Genebra e alguns jornais daqui. Dentro de alguns dias enviar-vos-ei o Constitucional. Tenho o pesar de vos anunciar a morte do pobre Chevrand, falecido no dia 8 e sepultado a 9 de novembro no Cemitério S. João Baptista, é pena, pois era um rapaz bom e honesto, que deixa saudades. Mas, em sua idade, a doença que tinha não perdoa e para ele mais vale estar no campo de repouso do que ter de sofrer ainda de 6 a 8 meses. Ele deixa uma filha que reconheceu perante várias testemunhas, mas não posso dizer se isto é suficiente para legitima-la. Porchat de Santos e eu o acompanhamos a sua última morada, havia muitos de nossos compatriotas e provavelmente pessoas de outras nações. Porchat permaneceu vários dias aqui por causa de seus negócios, hospedou-se em minha casa e voltou ontem, dia 11 para Santos. Seus negócios o retiveram bastante tempo, mas nada pode terminar, sendo obrigado a retornar em dezembro. Ele queria que nós subíssemos até vossa casa para fazer-vos uma visita, mas infelizmente o Steamer inglês que partiu a 9 nos impediu de acompanha-lo, de sorte que isto será para o próximo mês se ele vier e se me for possível. Na espera ele me encarrega de vos apresentar suas recomendações. O amigo Porchat não mudou nada, nem envelhece, é sempre o mesmo, alegre e jovial, está remoçando. Deus me castigue, como diziam nossos antepassados, mas teria gostado de dar um passeio com ele até o Taquaral, porém finalmente o que está adiado

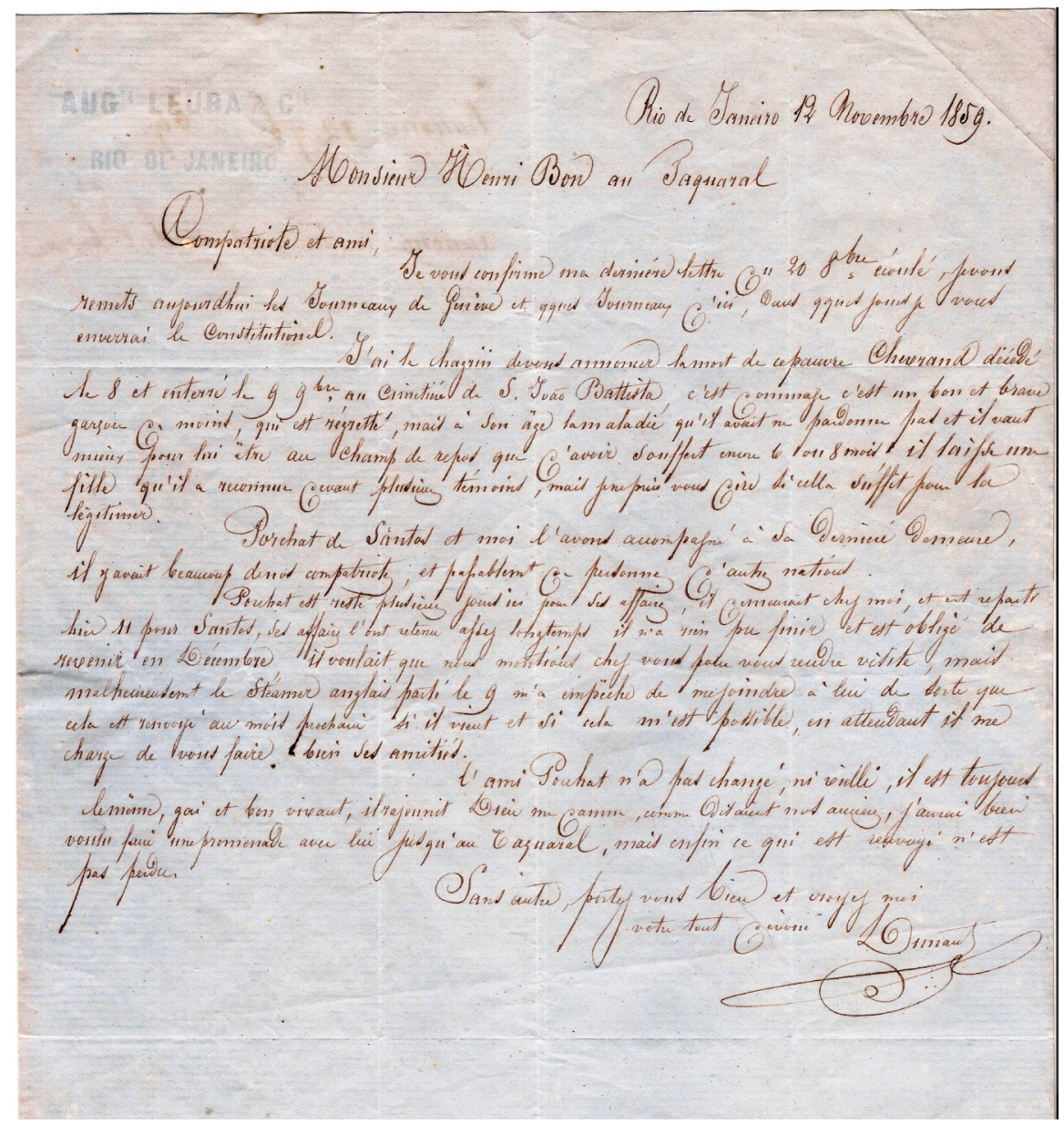

Figura 5 - Carta do suíço Maurice Dunant, redigida na cidade do Rio de Janeiro, para Henri Bon, em Cantagalo, no lugar denominado "Taquaral" (hoje chama-se Campo Alegre), datada de 12 de novembro de 1859. ${ }^{171}$ Fonte: Acervo particular de Henrique Bon. ${ }^{172}$

se tornou efetivamente um comerciante, mas assim como outros, simplesmente aproveitou uma oportunidade, e havia mercado consumidor para esses produtos.

No Jornal do Commercio da década de 1820, há uma seção intitulada "Importações", que informa o nome do navio chegado ao porto do Rio de Janeiro e de seu capitão, as mercadorias nele transportadas e seus destinatários. As firmas estrangeiras são a maioria desses receptores, com sobrenomes suíços aparecendo em várias delas. As mercadorias se originam de várias partes da Europa. Um anúncio de 2 de outubro de 1827 dizia:

Na Rua do Ouvidor no. 79, entre a Rua da Quitanda e o Beco das Cancellas, há para vender uma porção de trastes de mogno muito ricos, e de gosto muito moderno, chegados ultimamente de Hamburgo [região germânica], constando de secretárias de diversos feitios, grandes e pequenas, [...] toucadores grandes, e pequenos, espelhos de vestir, cômodas 
grandes e pequenas, mesas de escrever para senhoras, aparadores para sala de jantar, armários, e mesas para intervalos de sala, mesas para chá, e de sofá, cadeiras, canapés, escrivaninhas ${ }^{173}$ para escritório, armário para livros, berços, lavatórios, mesas de jogo, pianos fortes [antecessor do piano atual] e fortes pianos [forma tradicional de designar o piano atual, geralmente de cauda] de jacarandá muito ricos, relógios etc. ${ }^{174}$

comércio envolvendo negociantes estrangeiros demandava também um certo tipo de empregado. Um anúncio do dia seguinte informava:

Precisa-se de uma pessoa para ser empregada em um armazém de Molhados na vizinhança de Porto das Caixas, e que tenha conhecimento do mesmo negócio, assim como também conhecimento das línguas francesa, portuguesa, inglesa, ou alemã, a quem convier esta situação, e dando pessoa que afiance a sua conduta, queira dirigir-se à Rua Direita no. 193.175

A necessidade de um empregado que soubesse várias línguas em Porto das Caixas, porto fluvial que recebia mercadorias importadas, significava que os negociantes eram estrangeiros e que suas mercadorias seriam encaminhadas para o interior, inclusive para Minas Gerais, e não para a cidade do Rio de Janeiro, com Cantagalo sendo um dos destinos. A presença estrangeira em Cantagalo era tamanha que, no Jornal do Commercio de 4 de setembro de 1832, um anúncio pedia especialmente um sacerdote brasileiro: 176

O Povo do Curato do Sumidouro no Termo da Villa de São Pedro de Cantagalo, procura um Sacerdote Brasileiro para o servir, e the oferece anuário de 350\$000, com sua casa e passal [pedaço de terra], caso haja Sacerdote digno de o servir, pode falar ao Deputado Antônio João Lessa, rua do Cano no. 104, para the dar sua direção. ${ }^{177}$

contato entre estrangeiros residentes no Brasil e seus familiares ou amigos tradicionalmente comerciantes na Europa resultou em trocas culturais expressivas, influenciando e modificando hábitos de forma profunda. Ruralização, sim, dos novos habitantes estrangeiros, mas europeização também, de reinóis ou brasileiros, tanto os mais ricos, como os das famílias Soares e Moraes, quanto dos de pequenos e médios cabedais.

\section{CONCLUSÃO}

A montagem da agricultura cafeeira escravista em Cantagalo ocorreu em princípios do século 19 e se deu com pessoas originárias de Minas Gerais. Não foi uma migração de indivíduos isolados, mas de famílias: casais com ou sem filhos, não está perdido. Sem mais passai bem e crede-me vosso dedicado Dunant". Bon (2014, p. 165-166).

172. Agradeço a Henrique Bon pela permissão para publicar a carta de seu acervo particular.

173. Silva fornece o seguinte significado para escrivaninha: "caixa com o tinteiro, e o mais aparelho para se escrever" (1813, p. 743). Devo ressaltar que o dicionário foi escrito em 1789 (a edição de 1813 é idêntica à original), o termo "secretária", por exemplo, não refere a um móvel, mas a quem "guarda segrego, confidente" (1813, p. 675). Nenhum dos dois termos, secretária e escrivaninha, referem-se a móveis. "Mesas de escrever para senhoras", como está no anúncio, é um móvel. Provavelmente por estar a escrivaninha presente na mesa de escrever que deu origem ao que conhecemos hoje, escrivaninha: "móvel, geralmente dotado de escaninho, com um tampo fixo ou reclinável, sobre o qual se escreve; secretária".

174. Jornal... (1827, p. 4).

175. Ibidem, p. 4.

176. Grande parte dos imigrantes que se dirigiram para Nova Friburgo e, depois, foram para Cantagalo, era católica. Cf. Bon (2004).

177. Jornal... (1832, grifos meus). 
irmãos, tios e sobrinhos etc. Os que se dirigiram para Cantagalo tinham cabedal e condições para empreendimentos de vulto, a começar pela produção de artigos ligados ao abastecimento do mercado interno de alimentos e, depois, para o investimento em cafezais. $\bigcirc$ capital humano e financeiro que viabilizou o início da produção cafeeira de Cantagalo não se deu, definitivamente, por investimentos de comerciantes do Rio de Janeiro, mas certamente foram eles - o capital do tráfico de escravos e os representantes dos comerciantes de grosso trato leles mesmos não residiram na região) - que posteriormente investiram e lucraram com uma estrutura já montada: a ocupação da terra efetivada legalmente por meio de sesmarias e a certeza de que as condições geográficas e climáticas permitiam a instalação de cafezais.

Segundo Ricardo Salles, as elites cafeicultoras da bacia do Rio Paraíba do Sul que se consolidaram no poder estatal e no partido conservador na segunda metade do século $19^{178}$ tiveram um período de gestação de base regional, o que efetivamente ocorreu em Cantagalo. A formação das primeiras unidades produtoras de café foi tributária de capital originado no comércio interno, provavelmente da extração do ouro e da atuação de elementos oriundos do Brasil. Os grandes empresários das primeiras décadas do século 19, principalmente aqueles ligados ao comércio de grosso trato, construíram um esquema de sucesso para se inserir no mundo rural: o estabelecimento de "sociedades" entre eles e os sesmeiros residentes nos municípios que iniciavam o cultivo da rubiácea e, depois, a posse por compra ou por execução de dívidas de terras já cultivadas. Foi a estratégia utilizada por Antônio Clemente Pinto, em Cantagalo, um dos mais ricos empresários do Oitocentos, mas acredito que de outros também.

Por outro lado, a entrada do capital originário do tráfico de escravos em uma região interiorana e distante de portos e estradas viáveis criou condições de se formar um mercado consumidor de artigos sofisticados, como os que ofereciam os comerciantes estrangeiros de firmas estabelecidas na cidade do Rio de Janeiro ou os imigrantes europeus que mantinham contato frequente com suas famílias no outro lado do Atlântico. $\bigcirc$ conjunto de bens de vários inventariados até a década de 1830 primava, de maneira surpreendente, por objetos sofisticados e adquiridos por importação, em um momento que, teoricamente, a região ainda estava coberta de matas e era de difícil acesso, e a capital do novo Império engatinhava em tentar parecer mais europeia.

A chegada dos imigrantes suíços e, posteriormente, germânicos, franceses, holandeses etc., à extensa região de Cantagalo, só fez incrementar o gosto pelo consumo de artigos que esses imigrantes estavam prontos a oferecer com suas ligações europeias. Os relógios representam, simbolicamente, a grande influência 
europeia no interior do Rio de Janeiro. Medir o tempo, rigorosa e praticamente, não fazia parte do cotidiano dos habitantes do Brasil antes da chegada desses imigrantes.

A história dos usos e costumes de Cantagalo nas primeiras décadas do século 19 é somente um dos exemplos de como se formou uma sociedade agroexportadora escravista específica, resultado de um emaranhado de informações culturais que certamente nunca conseguiremos desvendar por completo. 


\section{REFERÊNCIAS}

FONTES MANUSCRITAS

ANA Joaquina do Amor Divino (inventário). 1815. Arquivo do Museu da Justiça do Estado do Rio de Janeiro. Pasta 501.

ANA Veloso do Espírito Santo (inventário). 1820. Arquivo Histórico da Casa Setecentista de Mariana.

ANTÔNIA Teixeira Soares (inventário). 1815. Arquivo do Museu da Justiça do Estado do Rio de Janeiro. Pasta 501.

ANTÔNIO Rodrigues de Moraes (inventário). 1833. Arquivo do Museu da Justiça do Estado do Rio de Janeiro. Pasta 504.

APONTAMENTOS estatísticos da Vila de São Pedro de Cantagalo. 1828. Seção de manuscritos da Biblioteca Nacional. II-35, 15, 57.

BON, Henrique. Henri Bon: um suíço no Brasil do século XIX. Nova Friburgo, 2006.

CARTA de Pedro Afonso Galvão de São Martinho a Luís da Cunha Meneses. 12 maio 1784. Arquivo Nacional. Códice 68, v. 6, p. 239-241-SC; Códice 238, p. 123.

CARTA de Sebastião Craveiro de Faria a Antônio Henriques. 1786. Seção colonial do Arquivo Público Mineiro. Códice 239, p. 73 v.

CARTA Régia. 1806. Arquivo Nacional. v. 47, fls. 262-263.

FRANCISCA Rosa da Câmara (inventário). 1817. Arquivo do Museu da Justiça do Estado do Rio de Janeiro. Pasta 501.

FRANCISCO Alves Filgueira (inventário). 1824. Arquivo do Museu da Justiça do Estado do Rio de Janeiro. Pasta 501.

FRANCISCO Alves Filgueira Marra (inventário). 1820. Arquivo do Museu da Justiça do Estado do Rio de Janeiro. Pasta 501. 
FRANCISCO Ferreira Guimarães (inventário). 1819. Arquivo do Museu da Justiça do Estado do Rio de Janeiro. Pasta 501.

JOÃO José Foli (inventário). 1820. Arquivo do Museu da Justiça do Estado do Rio de Janeiro. Pasta 501.

JOAQUIM José Soares (assento de óbito). $1^{\circ}$ set. 1817. In: LIVRO de assentos de óbito da Igreja do Santíssimo Sacramento de Cantagalo. 1789 a 1825. Arquivo da Matriz do Santíssimo Sacramento de Cantagalo. n. 1, p. 190.

JOSÉ Joaquim Soares (inventário). 1832. Arquivo do Museu da Justiça do Estado do Rio de Janeiro. Pasta 507.

LEÃO, Manoel Vieyra. Cartas topográficas da Capitania do Rio de Janeiro mandadas tirar pelo Ilmo. Exmo. Sr. Conde da Cunha Capitam General e Vice Rey do Estado do Brazil no anno de 1767. 1767. 16 mapas. Disponível em: <https://goo.gl/cMtCos>. Acesso em: 18 dez. 2016.

LIVRO de assentos de batizado da Igreja do Santíssimo Sacramento de Cantagalo. 1790 a 1825. Arquivo da Igreja do Santíssimo Sacramento de São Pedro de Cantagalo. Livro 1.

LIVRO de assentos de casamento da Igreja do Santíssimo Sacramento de Cantagalo. 1825 a 1836. Arquivo da Igreja do Santíssimo Sacramento de São Pedro de Cantagalo. Livro 2.

LIVRO de assentos de óbito da Igreja do Santíssimo Sacramento de Cantagalo. 1789 a 1825. Arquivo da Matriz do Santíssimo Sacramento de Cantagalo. n. 1.

PROCESSO matrimonial de Manoel Henriques e Maria de Sousa. $1^{\circ}$ jan. 1775. Arquivo Eclesiástico da Arquidiocese de Mariana. Registro n. 6632, Armário 6, Pasta 664, p. 4.

RELATÓRIO de inquirição de Pedro Afonso Galvão de São Martinho. 1786. Seção colonial do Arquivo Público Mineiro. Códice 239; p. 70 v.

REQUERIMENTO de João Clemente Pinto. 1804. Arquivo Histórico Ultramarino. Caixa 170, Documento 25 .

SEBASTIANA Maria (inventário). 1820. Arquivo do Museu da Justiça do Estado do Rio de Janeiro. Pasta 501.

SESMARIA a João Clemente Pinto. 1809-1812. Arquivo Nacional do Rio de Janeiro. Base de dados do Judiciário, Cantagalo. Notação 151-126, Microfilme 135-2005. 


\section{FONTES IMPRESSAS}

CONSTÂNCIO, Francisco Solano. Novo diccionário crítico e etymologico da língua portugueza.... Paris: Officina Typographica de Casimir, 1836.

DIÁRIO do Rio de Janeiro. Rio de Janeiro: Typographia do Diário, v. 290, n. 15, 17 out. 1821. Disponível em: <https://goo.gl/16stQi>. Acesso em: 5 abr. 2018.

Rio de Janeiro: Typographia do Diário, v. 196, n. 13, 15 jul. 1825a. p. 2. Disponível em: <https://goo.gl/ia7fmz>. Acesso em: 5 abr. 2018.

Rio de Janeiro: Typographia do Diário, v. 300, n. 23, 27 out. 1825b. Disponível em: <https://goo.gl/1drBGD>. Acesso em: 5 abr. 2018.

GAZETA do Rio de Janeiro. Rio de Janeiro: Impressão Régia, n. 96, 30 nov. 1814. Disponível em: <https://goo.gl/BPKtw5>. Acesso em: 5 abr. 2018.

Rio de Janeiro: Impressão Régia, n. 69, 8 jun. 1822. Disponível em: <https://goo.gl/ rfqHp3>. Acesso em: 5 abr. 2018.

JORNAL do Commercio. Rio de Janeiro: Imperial Typographia, v. 1, n. 2, 2 out. 1827. Disponível em: <https://goo.gl/TBVe7A>. Acesso em: 5 abr. 2018.

Rio de Janeiro: Imperial Typographia, v. 2, n. 75, 2 jan. 1828a. Disponível em: <https:// goo.gl/Tf1zo5>. Acesso em: 5 abr. 2018.

Rio de Janeiro: Imperial Typographia, v. 2, n. 127, 4 mar. 1828b. Disponível em: <https://goo.gl/J35qUu>. Acesso em: 5 abr. 2018.

Rio de Janeiro: Imperial Typographia, v. 2, n. 356, 12 dez. 1828c. Disponível em: $<$ https://goo.gl/zrGDYy>. Acesso em: 5 abr. 2018.

Rio de Janeiro: Imperial Typographia, v. 3, n. 480, 23 maio 1829. Disponível em: $<$ https://goo.gl/eCEXtT>. Acesso em: 5 abr. 2018.

Rio de Janeiro: Imperial Typographia, v. 7, n. 30, 4 set. 1832. Disponível em: <https:// goo.gl/K9pyXv>. Acesso em: 5 abr. 2018. 
SILVA, António de Moraes. Diccionario da lingua portugueza... 2. ed. Lisboa: Typografia Lacerdina, 1813.

O SPECTADOR Brasileiro. Rio de Janeiro: Typographia Plancher, n. 204, 25 nov. 1825. Disponível em: <https://goo.gl/5hrTe8>. Acesso em: 10 nov. 2017.

VASCONCELLOS E SOUZA, Luiz de. Ofício do Vice-Rei Luiz de Vasconcellos e Souza com a cópia da relação instrutiva e circunstanciada para ser entregue ao seu sucessor.... Revista Trimestral do Instituto Histórico e Geográfico Brasileiro, Rio de Janeiro, n. 13, p. 3-42, abr. 1842.

VIDE, Sebastião Monteiro da. Constituições primeiras do arcebispado da Babia: feitas, e ordenadas pelo Ilustríssimo, e Reverendíssimo Senhor D. Sebastião Monteiro da Vide: propostas, e aceitas em o Synodo Diocesano, que o dito Senhor celebrou em 12 de junho do anno de 1707. São Paulo: Typographia de Antonio Louzada Antunes, 1853. Disponível em: <https://goo.gl/ijjT44>. Acesso em: 5 abr. 2018.

\section{LIVROS, ARTIGOS E TESES}

ALMEIDA, Fernando Mendes de. (Org.). Ordenações filipinas: ordenações e leis do reino de Portugal recopiladas por mandato d'el rei D. Filipe, o primeiro. São Paulo: Saraiva, 1957. 5 v.

ALMEIDA, Gelsom Rozentino de. Hoje é dia de branco: o trabalho livre na Província Fluminense: Valença e Cantagalo (1870-1888). 1995. 204 f. Dissertação (Mestrado em História) - Instituto de Ciências Humanas e Filosofia, Universidade Federal Fluminense, Niterói, 1995.

ALVES, Romilda Oliveira. Fronteira em expansão: população, terra e família na Zona da Mata mineira: 1808-1850. 2009. 229 f. Dissertação (Mestrado em História) - Faculdade de Filosofia e Ciências Humanas, Universidade Federal de Minas Gerais, Belo Horizonte, 2009.

ANTUNES, Luís Frederico Dias. Têxteis e metais preciosos: novos vínculos do comércio indobrasileiro (1808-1820). In: FRAGOSO, J.; GOUVÊA, M. de F. S.; BICALHO, M. F. B. (Org.). $O$ antigo regime nos trópicos. Rio de Janeiro: Civilização Brasileira, 2001. p. 379-420.

BON, Henrique. Imigrantes: a saga do primeiro movimento migratório organizado rumo ao Brasil às portas da independência. 2. ed. Nova Friburgo: Imagem Virtual, 2004.

CARRARA, Ângelo Alves. Estruturas agrárias e capitalismo: contribuição para o estudo da ocupação do solo e da transformação do trabalho na Zona da Mata mineira: séculos XVIII e XIX. Mariana: Universidade Federal de Ouro Preto, 1999. v. 2. 
DIAS, Acácio Ferreira. Terra de Cantagalo: subsídio para a história do município de Cantagalo. Niterói: Diário Oficial, 1942.

DIAS, Acácio Ferreira. O Mão de Luva: fundador de Cantagalo. Niterói: Imprensa Oficial, 1953.

EISENBERG, Peter Louis. Modernização sem mudança: a indústria açucareira em Pernambuco, 1840-1910. Rio de Janeiro: Paz e Terra, 1977.

ERTHAL, Clélio. Cantagalo: da miragem do ouro ao esplendor do café. 2. ed. Rio de Janeiro: NitPress, 2008.

FARIA, Sheila de Castro. A colônia em movimento: fortuna e família no cotidiano colonial. Rio de Janeiro: Nova Fronteira, 1998.

FERNANDES, Rui Aniceto Nascimento. Historiografia e a identidade fluminense: a escrita da história e os usos do passado no estado do Rio de Janeiro entre as décadas de 1930 e 1950. 2009. 272 f. Tese (Doutorado em História) - Pontifícia Universidade Católica do Rio de Janeiro, Rio de Janeiro, 2009.

FERREIRA, Marieta de Moraes. Histórias de famílias: casamentos, alianças e fortunas. Rio de Janeiro: Léo Christiano, 2008.

FRAGOSO, João. Barões do café e sistema agrário escravista: Paraíba do Sul/Rio de Janeiro (1830-1888). Rio de Janeiro: 7 Letras, 2013.

FREYRE, Gilberto. Sobrados e mucambos: decadência do patriarcado rural e desenvolvimento do urbano. 14. ed. São Paulo: Global, 2003.

JORDÃO, Lia Ramos; CARNEIRO, Mônica. No Paraguai ou em Cantagalo? no verso de fronteira uma fotografia do século XIX, legendas que podem ser de D. Pedro II são as pistas para reescrever um passeio imperial. Revista de História da Biblioteca Nacional, Rio de Janeiro, $\mathrm{n}$. 103, p. 74-79, abr. 2014.

LAËRNE, Carl Frederik Van Delden. Brazil and Java: report on coffee-culture in America, Asia, and Africa. London: W. H. Allen, 1885.

LAGO, Bia Corrêa do; LAGO, Pedro Corrêa do. Coleção Princesa Isabel: fotografia do século XIX. 2. ed. Rio de Janeiro: Capivara, 2013. 
MALHEIROS, Márcia. Homens da fronteira: índios e capuchinhos na ocupação dos Sertões do Leste, do Paraíba ou Goytacazes: séculos XVIII e XIX. 2008. 401 f. Tese (Doutorado em História) - Instituto de Ciências Humanas e Filosofia, Universidade Federal Fluminense, Niterói, 2008.

MARRETO, Rodrigo Marins. De traficante de escravos a Barão de Nova Friburgo: a trajetória de Antônio Clemente Pinto na primeira metade do oitocentos. In: SIMPÓSIO NACIONAL DE HISTÓRIA, 28., 2015, Florianópolis. Anais... São Paulo: Anpuh, 2015. p. 1-12.

MORAES, Joaquim de Almeida Leite. Apontamentos de viagem. São Paulo: Companhia das Letras, 2011.

MUAZE, Mariana. As memórias da viscondessa: família e poder no Brasil Império. Rio de Janeiro: Zahar, 2008.

MUAZE, Mariana; SALLES, Ricardo (Orgs.). O Vale do Paraíba e o Império do Brasil nos quadros da segunda escravidão. Rio de Janeiro: 7 Letras, 2015.

NOTÍCIAS e reflexões sôbre as minas de Cantagallo (cujo extenso distrito começa a poucas léguas do Rio de Janeiro: escritas no fim do ano de 1805 por ****). Revista do Instituto Histórico e Geográfico Brasileiro, Rio de Janeiro, n. 12 , n. 5, p. 518-523, 1849.

OLIVEIRA, Rodrigo Leonardo de Sousa. "Mão de Luva" e "Montanha": bandoleiros e salteadores nos caminhos de Minas Gerais no século XVIII: Matas Gerais da Mantiqueira: 17551786. 2008. 189 f. Dissertação (Mestrado em História) - Instituto de Ciências Humanas, Universidade Federal de Juiz de Fora, Juiz de Fora, 2008.

INSTITUTO HISTÓRICO E GEOGRÁFICO BRASILEIRO. Anais do congresso comemorativo do bicentenário da transferência da sede do govêrno do Brasil da cidade do Salvador para o Rio de Janeiro. Rio de Janeiro: Imprensa Nacional, 1966.

SALLES, Ricardo Henrique. E o Vale era o escravo: Vassouras, século XIX: senhores e escravos no coração do Império. Rio de Janeiro: Civilização Brasileira, 2008.

. O Império do Brasil no contexto do século XIX: escravidão nacional, classe senhorial e intelectuais na formação do Estado. Almanack, Guarulhos, n. 4, p. 5-45, jul./dez. 2012.

SLENES, Robert Wayne. Os múltiplos de porcos e diamantes: a economia escravista de Minas Gerais no século XIX. Cadernos IFCH, Campinas, n. 17, p. 1-80, jun. 1985. 
SOUZA, José Antônio Soares de. As minas do sertão de Macacu. Revista do Instituto Histórico e Geográfico do Brasil, Rio de Janeiro, n. 326, p. 22-91, jan./mar. 1980.

STEIN, Stanley Julian. Vassouras: um munícipio brasileiro do café, 1850-1900. Rio de Janeiro: Nova Fronteira, 1990.

TSCHUDI, Johann Jakob von. Viagem às províncias do Rio de Janeiro e São Paulo. Belo Horizonte: Itatiaia, 1980.

VENÂNCIO, Renato Pinto. Os últimos Carijós: escravidão indígena em Minas Gerais: 17111725. Revista Brasileira de História, São Paulo, v. 17, n. 34, p. 165-181, 1997. Disponível em: <https://goo.gl/89GH7d>. Acesso em: 5 abr. 2018.

VINHAES, Eliana. Cantagalo: as formas de organização e acumulação da terra e da riqueza local. 1992. 257 f. Dissertação (Mestrado em História) - Instituto de Filosofia e Ciências Sociais, Universidade Federal do Rio de Janeiro, Rio de Janeiro, 1992.

Artigo apresentado em 22/11/2017. Aprovado em 14/03/2018

\section{(cc) BY}

